\title{
Momentum Periods of Feedback Trading toward Exchange Rate Volatility
}

\author{
Ivan Sudibyo', Aulia Keiko Hubbansyah² \\ ${ }^{1}$ Faculty of Economics and Business, Universitas Indonesia \\ ${ }^{2}$ Faculty of Economics and Business, Universitas Indonesia
}

\begin{abstract}
In this paper, the authors apply empirical evidence to demonstrate how important positive feedback trading factors in understanding exchange rate behavior. Utilizing the GARCH augmented feedback model, or the exchange rate model set out by Laopodis (2005), the author analyzes autocorrelation in exchange rate parameters and volatility in key ASEAN markets to yield the deeper understanding of momentum periods. The authors contend that positive feedback traders affect exchange rate volatility in ASEAN countries and induce the autocorrelation of negative returns within high exchange rate volatility. This study found that Singapore demonstrated a significant positive feedback trading during the period 1995-2014, while the authors further contend that Thailand, Indonesia, Malaysia, the Philippines, Brunei Darussalam, and Singapore also demonstrated positive feedback trading during the 1997-1998 Asian financial crisis. In addition to analyzing the positive feedback trading on exchange rate volatility, we also identify the exchange rate volatility spillover across the ASEAN countries. Related to this context, we found that Indonesia and Thailand play a dominant role as a dominant exchange rate volatility transmitter in the ASEAN region.
\end{abstract}

\section{Keywords:}

positive feedback trading, exchange rate volatility

1 ivansudibyo14@gmail.com

2 keikohubbansyah91@gmail.com 



\section{INTRODUCTION}

In this paper, we provide empirical evidence that confirms how important positive feedback trading is as a factor in exchange rate behavior in key ASEAN markets. Utilizing Laopodis' (2005) exchange rate model, we analyze autocorrelation of exchange rates and volatility for the deeper understanding of inducted exchange rates caused by the positive feedback trading behavior of the foreign exchange traders. Our thesis is that positive feedback traders affect exchange rate volatility in ASEAN countries and induce autocorrelation of negative returns within high exchange rate volatility.

Related to this concern, Keynes (1936) asserted that while investor sentiment and market psychology play important roles in financial markets, it is also almost impossible for individual economic agents to impound all market information so as to make consistently rational investment decisions, as the following renowned quote elaborates: "Investment based on genuine long-term expectation is so difficult as to be scarcely practicable. He who attempts it must surely lead much more laborious days and run greater risks than he who tries to guess better than the crowd how the crowd will behave; and, given equal intelligence, he may make more disastrous mistakes" (Keynes, 1936 quoted by Hommes, Cars.H., 2005). According to Keynes, it's hard to measure objective value from market fundamentals, and even were it possible, it will cost more to gather all relevant information in order to make such an assessment.

Indeed, the exchange rate markets do not reflect fundamental value for most of the time (De Grauwe \& Grimaldi, 2006). Messe and Rogoff (1983) provide the most distinguished empirical support of this perspective, one of a number of different exchange rate modeling approaches that emerged 
following the breakdown of the Bretton Woods exchange rate environment that prevailed up until the 1970s. Subsequent studies introduced non-linear features in exchange rate dynamics, such as initiated by Frankel and Froot (1987) and further developed in the context of stock prices (Brock and Hommes, 1998; Le Baron et al, 1999; Bohl and Reitz, 2002) (De Grauwe and Grimaldi, 2006) and Laopodis (2005). This paper is based on this approach. Some country's exchange rates can be affected by monetary policy and market forces, the latter reflecting the actions of traders. In this study, we will focus on analyzing the traders' influence toward exchange rate through volatility that is formed by their trading pattern. One indication of traders' force in determining exchange rates is through estimation of feedback trading.

\section{Research Contributions}

It is the authors' contention that feedback trading in ASEAN countries' the exchange rate markets causes increasing exchange rate volatility and causes such currencies to deviate from fundamental value, such as happened in the 1997-1998 Asian financial crisis. Hence, we make research of sub-periods analysis due to change in exchange rate policy and the effect towards exchange rate volatility.

The exchange rate feedback trading research scope of this paper covers key ASEAN countries including Thailand, Indonesia, Malaysia, the Philippines, Brunei Darussalam, and Singapore. Precedent research examined pre and post-crisis without analyzing sub-periods for exchange rate policy and its effect on exchange rate volatility.

The researcher motivation used the Laopodis model (2005) is to identified the positive feedback trading effect on exchange rate volatilities in ASEAN countries more detailed with momentum sub-periods analysis 
whereas the positive feedback trading was rarely discussed in precedent research about ASEAN countries' exchange rate volatility. The result will vary if the sample dates different, so we made the sub-periods based on the date when the policy changed. The momentum of periods shows us the difference of results.

The paper's research focus is on sub-periods crisis during the 19971998 period because several subject countries of this study changed their exchange rate system during this time in attempts to mitigate the monetary and real economic impacts of the 1997-1998 Asian Financial Crisis. Such sub-period study of the exchange rate volatility experienced by the indicated ASEAN countries is also examined in 2007-2008 Global Financial Crisis period and thereafter.

\section{LITERATURE REVIEW}

\section{1 The trader}

This paper refers to the studies on trader behavior conducted by Laopodis (2005), De Long et al (1990), Sentana and Wadhwani (1992). From feedback trading behavior patterns, they divide the traders into two distinct groups:

- Positive feedback traders; that is, those traders who buy when prices are high and sell when prices are low (Sentana et al. 1992; Laopodis, 2005).

- Negative feedback trader; those traders who sell when prices are high and buy when prices are low (Sentana et al. 1992; Laopodis, 2005). 


\section{2 Exchange Rate Model}

Feedback Trading in The exchange rate market - Laopodis Theoritical Model (2005). Despite the existence of economic agents assumed to behave in a rational manner that maximizes the fundamental of smart money, other investors (noise-trader) use random price or trend trading. Both investors' interactions create instability in asset prices that push those asset prices away from their fundamental value.

\section{2. 1 Rational Traders}

The first group of traders (smart money) are trying to maximize their portfolio's (N) function exclusively in return and risk factor (Sentana and Wadhwani, 1992). As result, this kind of investors will hold an optimal share fraction $\left(\mathrm{F}_{1, \mathrm{t}}\right)$ from the market portfolio as below:

$F_{1, t}=\left[\left(E_{t-1}\left(R_{t}\right)-\alpha\right) / k \sigma_{t}^{2}\right]$

Where Rt is ex-post return in $\mathrm{t}$ time, $\mathrm{E}_{\mathrm{t}-\mathrm{1}}$ is expectation operator in $\mathrm{t}-1$ time, $\propto$ is return level at risk-free asset, $\sigma_{\mathrm{t}}{ }^{2}$ is the conditional variance at $\mathrm{t}$ time and $\mathrm{k}$ is the coefficient representing risk aversion level from the investor. With assumption $\mathrm{k}$ is positive, $\mathrm{k \sigma t}_{\mathrm{t}}{ }^{2}$ is the premium risk that needed in $\mathrm{t}$ time. Equation (1) is a mean-variance model from every asset requests which implies the risk asset demand increases with the excess return as expected $($ Rt $-\propto)$ and reversing with $\sigma_{\mathrm{t}^{2}}$ risk level.

\section{2. 2 Noise Traders}

The second type of investor, the noise traders are assumed to follow a feedback strategy where they tend to buy while prices are increasing and tend to sell when prices are falling. Thus, their functional demand where $F_{2}$, $\mathrm{t}$ is share proportion owned by this group and $\mathrm{p}$ assumed positive. This strategy indicates noisy information trading, which is irrelevant in regards 
to the fundamental economy. Also, this will pull the asset price out like exchange rate from their essential value. Therefore, negative serial return correlation is seen as price increases followed by high demand that affects higher prices in the future. If $p<0$, negative feedback trading is seen as a trader who buys at low price and sells at high price. Market equilibrium requests all demand should be held by these two types of investor:

$$
F_{1, t}+F_{2, t}=1
$$

With the equality of (1) and (2), we can substitute the following

$$
R_{t}=a+k \sigma_{t}^{2}-k \sigma_{t}^{2} \rho R_{t-1}
$$

And we can assume the rational expectation until the equation no. 3 becomes stochastic as follows

$$
R_{t}=a+k \sigma_{t}^{2}-k \sigma_{t}^{2} \rho R_{t-1}+\varepsilon_{t}
$$

It indicates dependency in noise trader type, positive feedback trader will deliver negative serial correlation in return. It's common when the volatility level is higher, the negativity autocorrelation will increase. This point simply illustrates with the equation no. 5

$$
R_{t}=a+k \sigma_{t}^{2}+\left(\phi_{0}+\phi_{1} \sigma_{t}^{2}\right) R_{t-1}+\varepsilon_{t}
$$

Where the direct influence of noise trader (in constant level risk) comes from the positive sign in $\varnothing 0$.

Therefore, to calculate the effect of intense trading during exchange rate appreciation, it needs the augmentation of the equation no. 5 as follows:

$$
R_{t}=a+k \sigma_{t}^{2}+\left(\phi_{0}+\phi_{1} \sigma_{t}^{2}\right) R_{t-1}+\phi_{2}\left|R_{t-1}\right|+\varepsilon_{t}(6)
$$


We conclude a simple equation (6) into:

$R_{t}=a+k \sigma_{t}^{2}+\phi_{0} R_{t-1}+\phi_{1} \sigma_{t}^{2} R_{t-1}+\phi_{2}\left|R_{t-1}\right|+\varepsilon_{t}$

A positive feedback reflects in $\emptyset_{1}$ negative sign. The last part indicates the possibility of asymmetric trading behavior, where the negative return is followed by higher feedback trading volume if $\emptyset_{2}>0$. Positive and significant sign in asymmetric coefficient $\emptyset_{2}$ refers to the higher intention of positive feedback trading during appreciation rather than during depreciation. As cited in the Laopodis' previous research (2005), this paper will utilize the Generalized Error Distribution (Nelson,1991) as an assumption of error distribution, with the GED's parameter $r>0$. GED is a normal distribution if $r=2$ and a leptokurtic if $r<2$. If $r=1$, the distribution is double exponential (Nelson, 1991).

Related to the concern of this study, Laopodis' research (2005) indicated that there are $\emptyset_{0}$ negative autoregressive and significant parameter in Franc, Singaporean Dollar, Peseta, Greek Drachma, Rupee, and Ringgit for all periods. It means that there is a contrarian effect on those currencies. A $\emptyset_{0}$ positive autoregressive and significant parameter in Pound, Canadian Dollar, Mark, and Won indicated a bandwagon effect on those currencies.

An autoregressive $\emptyset_{1}$ parameter -that shows positive feedback trading and has similarity with herding (an agent who buy after prices increase)-will produce negative autocorrelation $\left(\emptyset_{1}\right.$ negative parameter value). On the contrary, negative feedback trading that has similarity with profit taking or a trader who sell after the price has increased will result in positive autocorrelation ( $\emptyset_{1}$ positive parameter value). A $\emptyset_{1}$ positive and significant parameter value shows in British Pound, denotes negative feedback trading exists in the British Pound. A $\emptyset_{1}$ negative and significant 
parameter value can be found in Canadian Dollar, Lira, Mark, Peseta, Rupee, Ringgit, Mexican Peso, Singapore Dollar, Won, and Baht. It indicates positive feedback trading on those currencies.

Asymmetric feedback trading signed by $\emptyset_{2}$ positive and significant parameter value. This leads into positive feedback trading that has intensively increased during appreciation rather than depreciation. It shows in Franc, Mark, Lira, Peseta, Mexican Peso, Rupee, and Won. A disparity value for an autocorrelation within pre- and post-crisis scenarios indicates a fluctuation in currency autocorrelation return. An autocorelation will have positive value during quiet periods and will have negative value during volatile periods (Sentana et al. 1992; Laopodis, 2005).

By nature, traders' asymmetric behavior indicates that they depend on central banks to gain short-term profit. This action can trigger instability in the foreign exchange market either by smart money or noise trader. Besides, this asymmetric action can lead to less credible account and shows that traders depend on central bank's reserve to gain short-term profit. In the end, ${ }^{\phi_{0}}$ positive and significant autoregressive parameter can be termed as the bandwagon effect, which occurs when past currency movement followed by expected currency movement is on the same route.

Price fluctuations in the market, where there can be an increase or also a decrease in prices can affect changes in the level of return. The efficient market hypothesis (EMH) states that the actual price reflects its fundamental value (Thaler, 2005). In an efficient market, an investor has a small chance to get a high return because the price is determined by a rational agent so that no investor is able to obtain an abnormal return from each investment strategy used. In addition to efficient markets, there are other levels of capital market efficiency which are then referred to as 
inefficient markets. In an inefficient market, an investor has a greater chance to get an abnormal return. This is referred to as a market anomaly because there is a market's deviation from the usual one. These market anomalies can provide abnormal positive or negative returns (Bodie, Kane, and Marcus, 2011). Broadly speaking, sentiment investors are often present when prices deviate from fundamental values (De Long, et all, 1990). Human feelings and emotions often influence their decisions, especially when those decisions involve risk and uncertainty. Emotional reactions and cognitive evaluations together guide one's reasoning. However, when both deviate, emotional reactions often dominate the behaviors that arise and influence the final decisions taken. In their research, many of these researchers then linked existing anomalous phenomena to behavioral finance. They see the possibility of psychological factors from the side of investors who control market reactions. Basically, standard finance is built on the rules of how investors "should" behave, compared to how investors actually behave. Investor behavior that needs to be taken into account is speculative behavior, namely the actor prefers exchange rate fluctuations (risk lover) to seek profits from fluctuations in exchange rates.

This study examined the behavior of traders before the 1998 crisis, the 1998 crisis, after the 1998 crisis, 2007-2008, and post-American crisis (QE phase 2 period until 2014). The results vary by country.

\section{METHOD, DATA AND ANALYSIS}

\section{1 Data Description}

This research used daily basis data of ASEAN currency exchange rate start from 1995 to 2014 . We used daily basis data in accordance with Laopodis(2005). To be informed, all exchange rates data toward US Dollar 
of the countries analyzed in this study were obtained from Thomson Reuters Datastream.

We made the sub-periods analysis arbitrary based on the date of authority change exchange rate policy, the period of US Financial crisis 2007-2008, and the period after US Financial crisis (2010-2014) which was begin with QE phase 2 period until 2014. These are the table periods;

\begin{tabular}{|c|c|c|c|}
\hline Countries & Code & Periods & Regimes \\
\hline Brunei & $\mathrm{BND}$ & 1967-now & pegged to $S G D$ \\
\hline \multirow[t]{2}{*}{ Singapore } & SGD & $1973-1985$ & crawling peg(basket currency) \\
\hline & & 1985- now & managed floating \\
\hline \multirow[t]{4}{*}{ Indonesia } & IDR & 1971-1978 & fixed exchange rate \\
\hline & & $1978-1992$ & managed floating \\
\hline & & 1992-1997 & $\begin{array}{l}\text { managed floating with crawling } \\
\text { band }\end{array}$ \\
\hline & & 14/08/1997-now & free floating \\
\hline \multirow[t]{4}{*}{ Malaysia } & MYR & 11/1984-06/1997 & managed floating \\
\hline & & 07/1997-08/1998 & free floating \\
\hline & & 09/1998-20/07/2005 & pegged to USD \\
\hline & & 21/07/2005-now & managed floating \\
\hline \multirow[t]{3}{*}{ Philippines } & PHP & 1980-1982 & crawling peg(USD) \\
\hline & & 1982-1984 & managed floating \\
\hline & & 1984-now & free floating \\
\hline \multirow[t]{5}{*}{ Thailand } & THB & $1978-1981$ & fixed exchange rate(USD) \\
\hline & & 1981-1982 & managed floating \\
\hline & & $1982-1984$ & crawling peg(USD) \\
\hline & & 1984-1997 & crawling peg(basket currency) \\
\hline & & 02/07/1997-now & free floating \\
\hline Cambodia & KHR & 1990-now & managed floating \\
\hline
\end{tabular}




\begin{tabular}{|l|l|l|l|}
\hline Laos & LAK & 1990 -now & managed floating \\
\hline Myanmar & MMK & $1977-02 / 04 / 12$ & Pegged to SDR \\
\hline & & $02 / 04 / 12-$-now & managed floating \\
\hline Vietnam & VND & $1993-31 / 01 / 1997$ & fixed exchange rate \\
\hline & & $\begin{array}{l}01 / 02 / 1997- \\
31 / 01 / 1999\end{array}$ & $\begin{array}{l}\text { fixed exchange rate with widened } \\
\text { band intervention }\end{array}$ \\
\hline & & $01 / 02 / 1999-n o w$ & managed floating \\
\hline
\end{tabular}

Resources: IMF: De Facto Classification of Exchange Rate Regimes and Monetary Policy Framework, IMF: Annual Report on Exchange Arrangements and Exchange Restrictions (2014), Hien(2007)

\section{2 Model Specification}

\section{Conditional variance}

The conditional variance of the returns $\left(\sigma_{t}^{2}\right)$ of various asset prices such as the exchange rate is found to be plagued by conditional heteroscedasticity as thus it can be modeled as a GARCH $(1,1)$ process as follows:

$\sigma_{t}^{2}=\alpha_{0}+\alpha_{1}\left(e_{t-1}^{2}\right)+\beta_{1}\left(\sigma_{t-1}^{2}\right)$

The parameter $\propto 1$ is 'autocorelation in volatility' indicating today's volatility is a function of the change/innovation squared of the exchange rate of the last period. The parameter $\beta 1$ is a representation of 'autoregressive nature of volatility', that is, current volatility is a function of the volatility of the last period. The Half-Life (HL) of a shock must be computed, which is defined as $\mathrm{HL}=\ln (0.5) / \ln (\alpha 1+\beta 1)$. The "HL" value shows how many days of volatility persist in each currency. And " $r$ " in the result table show GED (generalized error distribution) Parameter. 


\section{Estimation by Laopodis model (2005)}

We adopt the econometric model proposed by Laopodis (2005) which is called GARCH augmented feedback model. We apply Maximum Likelihood Estimation (BHHH algorithm) to estimate this model, with the equation as follows:

$$
R_{t}=a+k \sigma_{t}^{2}+\phi_{0} R_{t-1}+\phi_{1} \sigma_{t}^{2} R_{t-1}+\phi_{2}\left|R_{t-1}\right|+\varepsilon_{t}
$$

Where,

Rt: $\quad$ return in $\mathrm{t}$ time

a: constantan

$\mathrm{k}: \quad$ coefficient investor's degree of risk aversion

$\sigma_{t}^{2}: \quad$ conditional variants return

$\phi_{0}$ : the parameter that represents the autoregressive process in return, if negative indicates the contrarian effect (the previous deviation from the mean value that affects currency value moves in reverse). Whereas positive indicates the bandwagon effect (previous currency observation is expected to move forward)

$\phi_{1}$ : autocorrelation feedback trading parameter: if negative, it presents a positive feedback trader; if positive, it presents negative feedback trader.

$R_{t-1}:$ return in $\mathrm{t}-1$

$\phi_{2}$ : asymmetric trading behavior parameter: if positive, it denotes a negative return (exchange rate value appreciation). It's followed by a higher volume of feedback trading. In other words, positive feedback trading is more intense during appreciation rather than during depreciation.

$\left|R_{t-1}\right|$ :absolute value from the $\mathrm{t}-1$ return

$\varepsilon_{t}: \quad$ error term 


\section{Results}

After examining the periods 1995-2014, the ASEAN countries do not exhibit significant positive feedback trading. Only Singapore that shows significant positive feedback trading (at $\propto=5 \%$ ). The $\varnothing_{1}$ parameter value, in reaching thousands of units, indicates that the GARCH value in Singapore Dollars is very small, meaning that even if Singapore's Dollar has positive feedback trading, the Singapore currency is stable, fluctuating only in a small range. The table below shows estimate result during 1995-2014 using maximum likelihood estimation GARCH augmented feedback model.

Table 1. The Estimation Results

\begin{tabular}{|c|c|c|c|c|c|c|c|c|c|c|c|}
\hline No Countries & Periods & Model & k & $\Phi 0$ & $\Phi 1$ & $\Phi_{2}$ & $\alpha 0$ & $\alpha 1$ & $\beta 1$ & $r$ & $\mathrm{HL}$ \\
\hline 1 Indonesia & $1 / 1 / 1995-31 / 12 / 2014$ & $\operatorname{GARCH}(1,1)$ & 0,108179 & $-0,000352$ & $-1,798838$ & $-0,0031$ & $0,00000023^{* *}$ & $0.401017^{* *}$ & $0.731644^{* *}$ & $0.761625^{* *}$ & 5,564 \\
\hline prob & & & 0,6925 & 0,9734 & 0,3125 & 0,8254 & \begin{tabular}{|l|}
0.0000 \\
\end{tabular} & 0.0000 & 0.0000 & 0.0000 & \\
\hline 2 Malaysia & $1 / 1 / 1995-31 / 12 / 2014$ & $\operatorname{GARCH}(1,1)$ & 0,613392 & 0,007723 & $-19,95998$ & \begin{tabular}{|l|}
$-0,007387$ \\
\end{tabular} & $\begin{array}{r}0,00000000025^{*} \\
*\end{array}$ & $0.493388^{* *}$ & $0.738432^{* *}$ & $0.711784^{* *}$ & 3,3246 \\
\hline prob & & & 0,4435 & 0,4157 & 0,3814 & 0,4939 & 0.0000 & 0.0000 & 0.0000 & 0.0000 & \\
\hline 3 Thailand & $1 / 1 / 1995-31 / 12 / 2014$ & $\operatorname{GARCH}(1,1)$ & $-0,02288$ & 0,000157 & $-47,73276$ & $-0,000444$ & $0,0000000548^{* *}$ & $0.148054^{* *}$ & $0.871393^{* *}$ & $1.026591^{* *}$ & 35,988 \\
\hline prob & & & 0,9882 & 0,99 & 0,2131 & 0,9794 & 0.0000 & 0.0000 & 0.0000 & 0.0000 & \\
\hline 4) Philippines & $1 / 1 / 1995-31 / 12 / 2014$ & $\operatorname{GARCH}(1,1)$ & 0,560224 & $-0.023936^{\star}$ & $-77,48001$ & $-0,01876$ & $\begin{array}{r}0,00000000342^{*} \\
*\end{array}$ & $0.124357^{\star \star}$ & $0.893084^{* *}$ & $1.0414^{* *}$ & 40,088 \\
\hline prob & & & 0,7767 & 0,0485 & 0,3074 & 0,2451 & 0.0000 & 0.0000 & 0.0000 & 0.0000 & \\
\hline 5 Singapore & $1 / 1 / 1995-31 / 12 / 2014$ & $\operatorname{GARCH}(1,1)$ & 2,635466 & $-0,015648$ & $-1316.924^{*}$ & $-0,010148$ & $0,0000000579^{\star *}$ & $0.066105^{\star *}$ & $0.931445^{* *}$ & $1.281344^{\star *}$ & 282,57 \\
\hline prob & & & 0,607 & 0,3334 & 0,0229 & 0,6313 & 0,0002 & 0.0000 & 0.0000 & 0.0000 & \\
\hline 6 Brunei D. & $1 / 1 / 1995-31 / 12 / 2014$ & $\operatorname{GARCH}(1,1)$ & $-0,0376$ & 0,000082 & $-0,772018$ & $-0,000284$ & $0,000000156^{* *}$ & $0.092572^{\star \star}$ & $0.909251^{* *}$ & $0.772919 * *$ & 380,57 \\
\hline prob & & & 0,9701 & 0,9932 & 0,9207 & 0,9853 & 0,0000 & 0,0000 & 0.0000 & 0.0000 & \\
\hline 7 Cambodia & $1 / 1 / 1995-31 / 12 / 2014$ & $\operatorname{GARCH}(1,1)$ & 0,04838 & 0,000562 & $-0,606319$ & $-0,001498$ & $0,0000000158^{* *}$ & $0.707803^{* *}$ & $0.530158^{* *}$ & $0.546711^{\star \star}$ & 3,2471 \\
\hline prob & & & 0,8506 & 0,6866 & 0,5891 & 0,8977 & 0.0000 & 0.0000 & 0.0000 & 0.0000 & \\
\hline 8 Vietnam & 1/1/1995-31/12/2014 & $\operatorname{GARCH}(1,1)$ & $-1,15238$ & $-0.088325^{* *}$ & $-12,24466$ & $0.087888^{\star \star}$ & $0,0000000183^{* \star}$ & $0.167304^{* *}$ & $0.705865^{* *}$ & $1.009344^{* *}$ & 5,111 \\
\hline prob & & & 0,8414 & 0.0000 & 0,9527 & 0.0000 & 0.0000 & 0.0000 & 0.0000 & 0.0000 & \\
\hline 9 Myanmar & $1 / 1 / 1995-31 / 12 / 2014$ & NO ARCH EFFECT & & & & & & & & & \\
\hline prob & & & & & & & & & & & \\
\hline 10 Laos & $01 / 01 / 1995-31 / 12 / 201$ & NO ARCH EFFECT & & & & & & & & & \\
\hline prob & & & & & & & & & & & \\
\hline
\end{tabular}

S

${ }^{*}$ sig at $0.1 ; *$ sig at 0.01

As we see from the table above, the autoregressive parameter is significant in the Philippines and Vietnam. The Philippines has negative autoregressive parameter yet significant (at $\propto=5 \%$ ). This indicates a presence of contrarian effect in the Philippine currency during 1995-2014. This means previous currency movements resulted in the present currency 
moving in reverse. Vietnam has negative autoregressive parameter and significant (at $\propto=1 \%$ ). This also shows a presence of contrarian effect in Vietnam's currency during 1995-2014. Vietnam has a significant asymmetric trading behavior too ( $\varnothing_{2}$ positive and significant parameter). This indicates positive feedback trading in Vietnam's currency is more intense during appreciation rather than depreciation. Other ASEAN countries, during the period 1995-2014, are not indicated having any bandwagon effect or contrarian effect. Additionally, in the periods of 19952014, the other ASEAN countries are not indicated to have any asymmetric trading behavior. The "HL" value shows how many days of volatility persist in each currency.

\section{1 Sub-periods Exchange Rate Policy Analysis}

We made the sub-periods analysis arbitrary based on the date of authority change exchange rate policy, the period of US Financial crisis 2007-2008, and the period post US Financial crisis (2010-2014) which was begin with QE phase 2 period until 2014.

\section{a) Indonesia}

In table 2 below, we see Indonesia's currency displays no ARCH in 1995-1996 (before the Asian financial crisis). This shows Indonesia's currency was stable at that time. From early 1997 until before 14 August 1997, the Rupiah had begun to show an ARCH effect but no $\varnothing$ significant parameter. This is consistent with the fact that the Rupiah was, at this time, still managed under a floating rate within a crawling band policy. 
Table 2. Estimation Result for Indonesia

\begin{tabular}{|c|c|c|c|c|c|c|c|c|c|c|c|}
\hline No Countries & Periods & Model & a) & $k$ & $\Phi_{0}$ & $\phi_{1}$ & $\Phi 2$ & $\alpha_{0}$ & $a_{1}$ & $\beta_{1}$ & \\
\hline 1 Indonesia & 02/01/1995-31/12/1996 & NO ARCH EFFECT & & & & & & & & & \\
\hline \multicolumn{12}{|l|}{ prob } \\
\hline & $02 / 01 / 1997-13 / 08 / 1997$ & GARCH $(1,1)$ & 0,00000154 & $-0,681506$ & 0,004938 & $-173,7801$ & $-0,004701$ & $0.000000282^{*}$ & $0.544318^{*} \mathrm{C}$ & $0.605745^{* *}$ & $0.791666 * *$ \\
\hline \multirow[t]{2}{*}{ prob } & & & 0,9871 & 0,9477 & 0,9353 & 0,8273 & 0,9677 & 0,0826 & 0,0311 & 0.0000 & 0.0000 \\
\hline & $14 / 08 / 1997-31 / 12 / 1998$ & GARCH $(1,1)$ & 0,002043 & $-0,133022$ & $0.172647^{* *}$ & $-6.713448^{* *}$ & $-0,05331$ & $0.0000635^{*}$ & $0.162186^{*} \mathrm{C}$ & $0.818367^{* *}$ & $0.869269 * *$ \\
\hline \multirow[t]{2}{*}{ prob } & & & 0,1324 & 0,8039 & 0.0001 & 0,0043 & 0,4853 & 0,0589 & 0,0157 & 0.0000 & 0.0000 \\
\hline & 14/08/1997-31/12/2014 & GARCH(1,1) & 0,00000238 & $-0,00447$ & $-0,000503$ & $-1,377055$ & $-0,000469$ & $0.000000878^{* *}$ & $0.404217^{\star *}$ & $0.69695^{* *}$ & $0.781052^{* *}$ \\
\hline \multirow[t]{2}{*}{ prob } & & & 0,9496 & 0,9878 & 0,9507 & 0,4184 & 0,9727 & 0,0000 & 0.0000 & 0.0000 & 0.0000 \\
\hline & $07 / 2005-31 / 12 / 2014$ & $\operatorname{GARCH}(1,1)$ & $2,9300 \mathrm{E}-07$ & $-0,0116$ & $-0,0002$ & $-10,6756$ & 0,0005 & $0.000000229 * *$ & $0.225106^{* *} \mathrm{C}$ & $0.814472 * *$ & $0.784395 * *$ \\
\hline \multirow[t]{2}{*}{ prob } & & & 0,9944 & 0,9917 & 0,9887 & 0,7587 & 0,9841 & 0,0006 & 0,0000 & 0,0000 & 0,0000 \\
\hline & $2007-2008$ & NO ARCH EFFECT & & & & & & & & & \\
\hline \multicolumn{12}{|l|}{ prob } \\
\hline & After global crisis & $\operatorname{GARCH}(1,1)$ & $6,83 \mathrm{E}-06$ & $-0,194753$ & $0.052516^{*}$ & $-482.0333^{*}$ & 0,044698 & $0.000000129^{*}$ & $0.244688^{* *}$ & $0.80867^{* *}$ & $0.781586^{* \star}$ \\
\hline prob & Dec 2010-2014 & & 0,8773 & 0,9481 & 0,0259 & 0,017 & 0,2154 & 0,0225 & 0,0000 & 0,0000 & 0,0000 \\
\hline
\end{tabular}

${ }^{*}$ sig at $0.1 ;{ }^{* *} \operatorname{sig}$ at 0.01

On 14 August 1997, the Rupiah 's band intervention was released into a market mechanism called free-floating policy that has been applied until now. During this period, the research resulted from $\varnothing_{0}$ positive and significant parameter. This shows the presence of a bandwagon effect that is previous currency movement affected currency's expectation to move in the same way. Positive feedback trading appeared during this period by a presence of $\varnothing_{1}$ negative and significant parameter.

Indonesia's GDP growth in 1997 was $4.69 \%$ and in 1998 it plunged to $-13.12 \%$. The crisis impacted Indonesia's GDP growth drastically. While Indonesia's annual inflation rate (calculated from consumer prices) leaped higher from 6.22\% in 1997 to 58.38\% in 1998. From August 141997 until 2014, volatility appeared in the Rupiah exchange rate but showed no significant $\varnothing$ parameter that indicates the volatility affected by positive feedback trading, asymmetric trading, bandwagon nor contrarian effect.

Looking further at the above table, in the period 2007-2008, the Rupiah didn't exhibit ARCH effect. This was indicated that the Rupiah didn't volatile during this period. The 2007-2008 global financial crisis affected Indonesia's economy, this was evidenced by decreasing annual 
GDP growth rates from $6.34 \%$ in 2007 to $6.01 \%$ in 2008 . In 2007, annual inflation based on consumer prices in Indonesia was $6.4 \%$ and increased in 2008 to $9.77 \%$. Indonesia's current account balance, as a percentage of GDP, also decreased from $2.42 \%$ in 2007 to $0.0024 \%$ in 2008 .

We also examined the post-global financial crisis period from the end of 2010 until 2014. The Federal Reserve, The US Central Bank adopted an unprecedented quantitative easing policy. On November 2010, The Fed declared to begin QE phase 2 (Federal Reserve, November 2010). In 2013, The Fed began tapering to reduce bond purchasing since 18 December 2013 (CNBC News, 2013). These Federal Reserve policy settings over the 20102014 period affected Indonesia's exchange rate. A ø0 positive autoregressive and significant parameter emerged in the Rupiah. Meanwhile, $\varnothing 1$ negative and significant parameter indicated a bandwagon effect and positive feedback trading during that period.

The Rupiah's exchange rate had sloppy trend during this time. Autoregressive parameters showed the bandwagon effect, a previous currency movement affected currency's expectation to move in the same way during this period. Hence, volatility in Rupiah during this time also was affected by positive feedback trading. In this period, annual GDP growth was decreasing from $6.2 \%$ in 2010 to $5.0 \%$ in 2014 ., while the current account surplus as a percentage of GDP also decreased from 0.7\% in 2010 and moved to a deficit of $-3.2 \% 2013$.

\section{b) Malaysia}

Similar to the Indonesian Rupiah, Malaysia's Ringgit also didn't demonstrate the ARCH effect before the Asian financial crisis period (based on data in the period 1995-30/06/1997). From July 1997 to August 1998, however, the Ringgit detached its value into floating. This was proved in 
the data by the presence of ARCH effect in Ringgit. Meanwhile, there was no $\varnothing$ significant parameter during this time. However, Malaysia obviously experienced the crisis' effect with GDP decreasing on an annual percentage basis from $7.3 \%$ in 1997 to $-7.3 \%$ in 1998 . At the same time, inflation on an annual percentage basis based on consumer price crawled higher from $2.66 \%$ in 1997 to $5.27 \%$ in 1998 . The lowest Ringgit rate occurred on 8 January 1998, when it hits 4.6805 to the United States dollar.

Table 3. Malaysia Estimation Results

\begin{tabular}{|c|c|c|c|c|c|c|c|c|c|c|c|}
\hline No Countries & Periods & Model & $\mathrm{a}$ & $k$ & $\Phi_{0}$ & $\Phi_{1}$ & $\Phi_{2}$ & $\alpha 0$ & $\alpha_{1}$ & $\beta 1$ & \\
\hline 2 Malaysia & 02/01/1995-30/06/1997 & NO ARCH EFFECT & & & & & & & & & \\
\hline \multicolumn{12}{|c|}{ 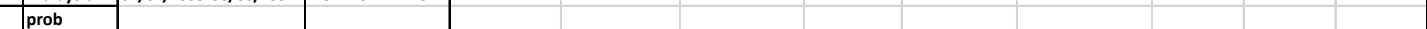 } \\
\hline & 01/07/1997-31/08/1998 & $\operatorname{GARCH}(1,1)$ & $0.00126^{*}$ & $\begin{array}{ll}-0,884495 \\
-1\end{array}$ & 0,027907 & $-38,52741$ & 0,05094 & $5,33 \mathrm{E}-06$ & $0.109995^{*}$ & $0.87854^{* *}$ & $1.054552^{* *}$ \\
\hline prob & & & 0,0821 & 0,6404 & 0,6985 & 0,3941 & 0,5703 & 0,1486 & 0,0111 & 0.0000 & 0.0000 \\
\hline & 09/1998-31/12/1998 & GARCH $(1,1)$ & 0,0001 & $-6,2251 \mathrm{E}-01$ & $0.878278^{* *}$ & $-913.4873^{* *}$ & $-0.937503^{* *}$ & $0.000000233^{* *}$ & $0.809532^{* *}$ & $0.139062^{* *}$ & $1.737544^{* *}$ \\
\hline prob & & & 0,5762 & 0,2638 & 0,0000 & 0,0000 & 0,0000 & 0,0000 & $\begin{array}{r}0,0004 \\
\end{array}$ & 0,0095 & 0,0000 \\
\hline & 09/1998-20/07/2005 & $\operatorname{GARCH}(1,1)$ & $\begin{array}{ll}3,81 \mathrm{E}-09 \\
\end{array}$ & 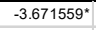 & $-0.129247^{* \star}$ & $-48,04654$ & $-0.153701^{* *}$ & $0.000000000117^{* *}$ & $0.028744^{* \star}$ & $0.79958^{* *}$ & $0.609419^{* *}$ \\
\hline prob & & & 0,9948 & 0,0575 & 0.0000 & 0,5547 & 0.0000 & 0,0000 & 0.0000 & 0.0000 & 0.0000 \\
\hline & 2007-2008 & GARCH $(1,1)$ & $-0,0000824$ & 0,023844 & $0.161737^{* *}$ & $-2498.654^{* *}$ & 0,016359 & $7,83 \mathrm{E}-08$ & $0.265345^{* *}$ & $0.79888^{* *}$ & $0.982996^{* *}$ \\
\hline prob & & & 0,3767 & 0,9975 & 0,0021 & 0,0097 & 0,8067 & 0,2439 & 0.0000 & 0.0000 & 0.0000 \\
\hline & $21 / 07 / 2005-31 / 12 / 2014$ & GARCH $(1,1)$ & $-0,00000291$ & $7.400178^{*}$ & $0.047004^{*}$ & $-639.8292^{*}$ & $-0.069351^{*}$ & $4,06 \mathrm{E}-09$ & $0.155886^{* *}$ & $0.874154^{* *}$ & $1.050412^{* *}$ \\
\hline prob & & & 0,9283 & 0,0269 & 0,0492 & 0,0925 & 0,0248 & 0,1893 & 0.0000 & 0.0000 & 0.0000 \\
\hline & After global crisis & GARCH $(1,1)$ & $\begin{array}{l}-9,03 \mathrm{E}-05 \\
\end{array}$ & $13.13979^{*}$ & 0,017666 & $\begin{array}{ll}-190,2781 \\
\end{array}$ & $-0,070041$ & $0.000000538^{*}$ & $0.080107^{* \star}$ & $0.889356^{* *}$ & $1.154591^{\star \star}$ \\
\hline prob & Dec 2010-2014 & & 0,5272 & 0,0146 & 0,6952 & 0,7949 & 0,1672 & 0,0429 & 0,0003 & $\begin{array}{l}0,0000 \\
\end{array}$ & 0,0000 \\
\hline
\end{tabular}

*sig at $0.1 ;{ }^{* *}$ sig at 0.01

From September 1998 until 20 July 2005, Malaysia employed a fixed exchange rate system which was pegged toward US\$ and floating toward other currencies. This is seen in $\varnothing_{0}$ and $\varnothing_{2}$ significant parameters derived in the author's modeling of the Ringgit's performance during this period. A $\varnothing_{0}$ negative and significant parameter indicated that the Ringgit had experienced the contrarian effect and that a previous currency movement affected crosscurrent expectations during that period. Additionally, $\varnothing_{2}$ denoted negative and significant number. We can conclude that during the sub-period policy, an asymmetric trading behavior emerged in Ringgit and showed no significant positive feedback trading during this time. Therefrom, Ringgit was pegged to US\$ movement at this period and just in fact, Ringgit moved around 3.8 US\$.

After economic conditions had stable following the Asian financial crisis, Malaysia removed the Ringgit from its peg to the United States dollar 
on July $21^{\text {st }} 2005$ after China removed the Renminbi from its peg to the United States dollar. From July $21^{\text {st }}$ 2005, Malaysia applied a managed floating exchange rate system once again.

We found a presence of $\varnothing_{0}, \varnothing_{1}$, and $\varnothing_{2}$ significant parameter from 21 July 2005 until the end of 2014. A $\varnothing_{0}$ positive and significant parameter denoted a bandwagon effect during this time. Positive feedback trading was indicated by a presence of $\varnothing_{1}$ parameter during this period. Meanwhile, a $\varnothing_{2}$ negative and significant parameter showed asymmetric trading behavior during that period. In other words, positive feedback trading was more intense during depreciation rather than appreciation.

Ringgit had $\varnothing_{0}$ and $\varnothing_{1}$ significant parameter during 2007-2008. A bandwagon effect emerged during this period by a presence of $\varnothing_{0}$ parameter. A big number and $\varnothing_{1}$ negative parameter value showed a positive feedback trading during this period, albeit with a small range fluctuation. In the Malaysian economic system, 2007's annual GDP percentage growth was $6.29 \%$ and decreased to $4.83 \%$ in 2008 , while the annual percentage change in inflation based on consumer prices grew from $2.02 \%$ to $5.44 \%$ in 2008 . During this time period, Malaysia's current account balance itself increased from 15.3 in 2007 to 16.8 (\% of GDP) in 2008.

There was a volatility in the Ringgit at the end of period 2010-2014, but it showed no $\varnothing$ significant parameter. This means that the volatility in the Ringgit wasn't affected by positive feedback trading, asymmetric trading, bandwagon nor contrarian effect. A variable macroeconomic performance was seen in Malaysia during the 2010-2014 period, but in 20132014, it climbed from 4.73 in 2013 to 6.03 (\% of GDP). Malaysia's current account balance was lowering but still in positive condition. Malaysia's 
current account balance was recorded 10.906 (\% of GDP) in 2010 and 3.74 in 2013 (\% of GDP).

\section{c) Thailand}

The Baht demonstrated the ARCH effect just before the crisis period (1995-1996), but had no $\varnothing$ significant parameter. In the crisis period (early 1997 until mid-1997) there was $\varnothing_{0}$ negative and significant parameter. This indicated a presence of contrarian effects in the trading of the Baht during that period. During 14-15 May 1997, the Baht was hit by enormous speculative attacks (Hoontrakul,2001). On July 2nd, 1997 after spending billions of dollars to defend Baht, the Thai Central Bank was forced to let its currency float (Yoon, I.H., 2006). The Thai Baht fell to its lowest point at 56 to the United States dollar on January 12th, 1998, (Yoon, I.H., 2006). During the deepest of the crisis period from July $2^{\text {nd }}, 1997$ until December $31^{\text {st } 1998,}$ the Baht exchange rate showed a bandwagon effect and positive feedback trading. Due to this crisis, Thailand's GDP growth was declining. In 1997 Thailand's annual GDP percentage growth was $-1.4 \%$ and in 1998 plunged to $-10.5 \%$. Meanwhile, based on annual percentage changes in consumer prices, inflation in Thailand went higher from 5.6\% in 1997 to $8.0 \%$ in 1998 . Thailand's current account balance in 1997 was valued -2 \% of GDP. 
Table 4. Thailand Estimation Result

\begin{tabular}{|c|c|c|c|c|c|c|c|c|c|c|c|}
\hline No Countries & Periods & Model & $a$ & $k$ & $\phi_{0}$ & $\Phi_{1}$ & $\Phi_{2}$ & $\alpha_{0}$ & $a_{1}$ & $\beta_{1}$ & \\
\hline \begin{tabular}{l|l}
3 & Thailand \\
\end{tabular} & 02/01/1995-31/12/1996 & $\operatorname{GARCH}(1,1)$ & 0,000101 & $-29,77067$ & $-0,049986$ & 19785,96 & $-0,013797$ & $0.0000000334^{*}$ & $0.047783^{*}$ & $0.916995^{* *}$ & $1.137272^{* *}$ \\
\hline prob & & & 0,1414 & 0,5775 & 0,5007 & 0,5196 & 0,8272 & 0,0805 & 0,0481 & 0.0000 & 0.0000 \\
\hline & 01/01/1997-01/07/1997 & $\operatorname{GARCH}(1,1)$ & 0,00023 & 4,729407 & $-0.233357^{* *}$ & $-285,623$ & $-0,1953$ & 0.000000233 & $0.782481^{*}$ & $0.592685^{* *}$ & $0.841169^{* \star}$ \\
\hline prob & & & 0,0639 & 0,3937 & 0,0098 & 0,3151 & 0,1322 & 0,4241 & 0,053 & 0,0004 & 0.0000 \\
\hline & 02/07/1997-31/12/1998 & $\operatorname{GARCH}(1,1)$ & $-0.001128^{*}$ & 2,0166 & $0.116529 *$ & $-177.326^{* *}$ & 0,0691 & $0.000025^{* *}$ & $0.467093^{* *}$ & $0.542638 * *$ & $0.907214^{* *}$ \\
\hline & & & 0,0324 & 0,2222 & 0,0265 & 0,0026 & 0,2847 & 0,0051 & 0,0014 & 0,0000 & 0,0000 \\
\hline & 02/07/1997-31/12/2014 & GARCH $(1,1)$ & $-0,00000122$ & 0,021686 & 0,00036 & $-44,70618$ & 0,000199 & $0.000000263^{* *}$ & $0.144386^{* *}$ & $0.8527^{* *}$ & $1.05624^{* *}$ \\
\hline prob & & & 0,9788 & 0,9898 & 0,9791 & 0,3414 & 0,992 & 0,0000 & 0.0000 & 0.0000 & 0.0000 \\
\hline & $05 / 2000-31 / 12 / 2014$ & $\operatorname{GARCH}(1,1)$ & $-1,1500 \mathrm{E}-07$ & $-0,7610$ & 0,0006 & $-109,8435$ & 0,0017 & $0.000000301^{* *}$ & $0.158975^{* *}$ & $0.836292^{* *}$ & $1.056805^{* *}$ \\
\hline prob & & & 0,9981 & 0,7839 & 0,9673 & 0,1377 & 0,9385 & 0,0000 & 0,0000 & 0,0000 & 0,0000 \\
\hline & 2007-2008 & $\operatorname{GARCH}(1,1)$ & 0,000301 & $-1,474605$ & 0,013949 & $-25,54712$ & $-0,019957$ & $0.00000706^{* *}$ & $0.668198^{* *}$ & $0.484566^{* *}$ & $0.741343^{* *}$ \\
\hline prob & & & 0,0139 & 0,0897 & 0,6667 & 0,8312 & 0,567 & 0,0061 & 0,0009 & 0.0000 & 0.0000 \\
\hline & After global crisis & $\operatorname{GARCH}(1,1)$ & $-2,14 \mathrm{E}-05$ & $-0,131412$ & $-0,002294$ & $-791,9062$ & 0,028256 & $0.000000259^{*}$ & $0.089813^{* *}$ & $0.886711^{* *}$ & $1.232899^{* *}$ \\
\hline prob & Dec 2010-2014 & & 0,8679 & 0,9928 & 0,9663 & 0,7932 & 0,5716 & 0,0142 & 0,0001 & 0,0000 & 0,0000 \\
\hline
\end{tabular}

${ }^{*}$ sig at $0.1 ;{ }^{* *}$ sig at 0.01

At the end of the period 2010-2014, the authors modeling highlights the volatility in the Thai Baht, but the research also pointed to an absence of $\varnothing$ significant parameter in the Baht, therefore indicating that the volatility wasn't affected by positive feedback trading, asymmetric trading, bandwagon nor contrarian effect.

During this period, Thailand experienced variable economic growth in terms of annual percentage changes in GDP growth, moving from $7.8 \%$ in 2010 to $0.7 \%$ in 2014 . The current account balance in Thailand decreased during this period: In 2009, the current account balance was 8.3 (\% of GDP) and then the negative current account balance happened in 2012-2013, hitting -0.3984 in 2012, easing further down to -0.97644 (\% of GDP) in 2013, but recovering in 2014 to $3.51 \%$ of GDP.

\section{d) Vietnam}

Vietnam maintained the Vietnamese Dong (VND) in point around 10.000-11.000 for 3 years, 1993-1996 (Hien, 2007). The research showed that Vietnam had the ARCH effect in early 1995 until January 1997. Additionally, $\varnothing_{0}$ parameter denoted positive and significant value. This indicated that the bandwagon effect existed in the VND at that time. The $\varnothing_{1}$ 
parameter in the VND yielded negative yet significant value, on the contrary the parameter had a big number. It exhibited a positive feedback trading on the currency, even occurred the fluctuation in a very small range. As a result, the VND exchange rate pushed to its lowest point (it was from 1995 until January 1997). On January 17, 1997, the exchange rate was hitting 11180. While $\varnothing 2$ negative and significant parameter value termed as a presence of the asymmetric trading behavior in the period. The positive feedback trading was more intense during depreciation rather than appreciation. During the Asian financial crisis (1997-1998), Vietnam expanded its band-intervention to $\pm 5 \%$ in February 1997 and $\pm 10 \%$ in October 1997.

Table 5. Vietnam Result Estimation

\begin{tabular}{|c|c|c|c|c|c|c|c|c|c|c|c|}
\hline No Countries & Periods & Model & $\mathrm{a}$ & $k$ & $\Phi_{0}$ & $\Phi_{1}$ & $\Phi_{2}$ & $\alpha 0$ & $a_{1}$ & $\beta_{1}$ & \\
\hline 4 Vietnam & 02/01/1995-31/01/1997 & GARCH $(1,1)$ & $-0.0000419 *$ & $738.8006 * *$ & $0.032935 *$ & $-806555.4^{* *}$ & $-0.079674^{* *}$ & $0.00000000227^{*}$ & $0.124039 * *$ & $0.821613^{* *}$ & $0.507143^{* *}$ \\
\hline \multirow[t]{2}{*}{ prob } & & & 0,0000 & 0,0000 & 0,0772 & 0,0000 & 0,0000 & 0,0166 & 0,0086 & 0.0000 & 0.0000 \\
\hline & 01/02/1997-31/01/1999 & NO ARCH EFFECT & & & & & & & & & \\
\hline \multicolumn{12}{|l|}{ prob } \\
\hline & 01/02/1999-31/12/2014 & GARCH $(1,1)$ & 0,000000368 & $-5,531236$ & $-0.173693 *$ & 365,4061 & $0.163149^{* *}$ & $0.00000000127^{* *}$ & $0.124497 * *$ & $0.871726^{* *}$ & $1.084233 * *$ \\
\hline \multirow[t]{2}{*}{ prob } & & & 0,9425 & 0,5544 & 0.0000 & 0,3091 & 0.0000 & 0,0000 & 0.0000 & 0.0000 & 0.0000 \\
\hline & 2007-2008 & GARCH $(1,1)$ & 0,00000066 & 0,682373 & $-0,000872$ & $-286,1015$ & $-0,001408$ & $0.0000000514^{* *}$ & $0.279101^{\text {** }}$ & $0.716467^{* *}$ & $0.696813^{* *}$ \\
\hline \multirow[t]{2}{*}{ prob } & & & 0,9746 & 0,9505 & 0,9789 & 0,9212 & 0,9709 & 0,0001 & 0.0000 & 0.0000 & 0.0000 \\
\hline & After global crisis & NO ARCH EFFECT & & & & & & & & & \\
\hline prob & Dec 2010-2014 & & & & & & & & & & \\
\hline
\end{tabular}

${ }^{*}$ sig at $0.1 ;{ }^{* *} \operatorname{sig}$ at 0.01

We highlight Vietnam's GDP growth (in 1997-1998) was decreasing but the value was still positive at 8.15 in 1997 and became 5.76 in 1998. The inflation based on consumer price in 1997, Vietnam had 3.2 inflation rate and increased to 7.26 in 1998. The VND exchange rate pushed to its lowest (13907) on August $24^{\text {th }}, 1998$. It signified, even applied managed floating system, the VND still pushed to the lowest rate.

This research showed that there was no ARCH effect in the VND from February $1^{\text {st }}, 1997$ until January 31 ${ }^{\text {st }}, 1999$. It indicated that SBV played a significant role during this period in the VND movement. After the 
financial crisis period in February 1999 until 2014, Vietnam changed its currency system into the managed float regime. We can see $\varnothing_{0}$ negative and significant parameter. It indicated a presence of contrarian effect during this period. Also, this indicated that the VND had a significant asymmetric trading behavior ( $\varnothing 2$ positive and significant parameter). This showed that a positive feedback trading in VND had more intense in appreciation rather than in depreciation.

The Vietnamese Dong (VND) experienced an ARCH effect without $\varnothing$ significant parameter during 2007-2008. Vietnam's GDP growth decreased from 7.12 in 2007 to 5.66 in 2008. Based on consumer price, Vietnam's inflation went higher from 8.3 in 2007 to 23.11 in 2008 . Vietnam's current account balance fell from -8.98 in 2007 to -10.91 (\% of GDP) in 2008. At the end of the period 2010 until 2014, the VND signed no ARCH effect. It concluded that there was no volatility in the VND during this period. Hence, SBV maintained the VND exchange rate during this period. Vietnam's GDP growth in this period was quite good, it was valued $>5$. In 2013, GDP growth was in 5.42 and moved to 5.98 in 2014. Vietnam's current account balance was moving from -3.68 in 2010 to 5.81 in 2012 and decreased slightly in 2013 to 5.53 (\% of GDP). Though SBV maintained the exchange rate with managed float system, the VND exchange rate still lowered from 2010 until 2014. The VND exchange rate was 18469 in early January 2010 and hit its lowest point on November 27th, 2014 to 21390.

\section{e) Philippine}

The Philippine Peso had been used the floating system before the crisis. Though, they still paid the effect of 1997-1998 the Asian financial crisis. This denoted $\varnothing_{0}$ positive and $\varnothing 1$ negative significant parameter. The author concludes that the Philippine Peso (PHP) experienced a bandwagon 
effect and positive feedback trading behavior during this period. The exchange rate pushed to its lowest point on January $6^{\text {th }}, 1998$ to 45.2 . This affected the Philippines GDP growth fell down. It fell from 5.18 in 1997 to 0.57 in 1998. It followed by the inflation increment based on consumer price, from 5.59 in 1997 to 9.23 in 1998. There signed no ARCH effect in 2007-2008. Meanwhile, the financial crisis impacted the PHP that denoted in the decrement of GDP growth from 6.61 in 2007 to 4.15 in 2008. The inflation also increased in 2007. Based on consumer price, inflation went almost tripled from 2.9 to 8.26 in 2008. The Philippine's current account balance during 2007-2008 fall from 5.40 in 2007 to 0.08 (\% of GDP) in 2008.

Table 6. Philippine Estimation Result

\begin{tabular}{|c|c|c|c|c|c|c|c|c|c|c|c|}
\hline No Countries & Periods & Model & a & $k$ & $\phi_{0}$ & $\phi_{1}$ & $\phi_{2}$ & $\alpha 0$ & $a_{1}$ & $\beta_{1}$ & \\
\hline 5 Philippines & 02/01/1995-31/12/1996 & GARCH(1,1) & 0,000000334 & $-0,4696$ & $-0.067297^{*}$ & $-1209,4020$ & $-0,0615$ & $0,0000000114^{*}$ & $0,144291^{*}$ & $0,876291^{* *}$ & $0,75874^{* *}$ \\
\hline \multirow[t]{2}{*}{ prob } & & & 0,9905 & 0,9571 & 0,0189 & 0,3297 & 0,1671 & 0,0402 & 0,0154 & 0,0000 & 0,0000 \\
\hline & $1 / 1 / 1997-31 / 12 / 1998$ & GARCH(1,1) & 0,000000537 & $-2,122548$ & $0.249147^{* *}$ & $-430.1327^{\star *}$ & 0,025304 & $0.0000000138^{*}$ & $0.3505^{* *}$ & $0.710945^{* *}$ & $0.713202^{* *}$ \\
\hline \multirow[t]{2}{*}{ prob } & & & 0,9831 & 0,1933 & 0.0000 & 0,0001 & 0,5082 & 0,0774 & 0.0000 & 0.0000 & 0.0000 \\
\hline & 01/2002-31/12/2014 & GARCH $(1,1)$ & $2,9300 \mathrm{E}-06$ & $2,2862 E+00$ & $-0.065955 *$ & 236,3854 & $-0,0289$ & $0.000000064^{* *}$ & $0.061829 * *$ & $0.935518^{* *}$ & $1.369529 * *$ \\
\hline \multirow[t]{2}{*}{ prob } & & & 0,9679 & 0,6928 & 0,0115 & 0,8121 & 0,2945 & 0,0078 & 0,0000 & 0,0000 & 0,0000 \\
\hline & 2007-2008 & NO ARCH EFFECT & & & & & & & & & \\
\hline & & & & & & & & & & & \\
\hline & After global crisis & NO ARCH EFFECT & & & & & & & & & \\
\hline prob & Dec 2010-2014 & & & & & & & & & & \\
\hline
\end{tabular}

${ }^{*}$ sig at $0.1 ;{ }^{* *} \operatorname{sig}$ at 0.01

After the crisis at the end of 2010 until 2014, the PHP experienced no ARCH effect. This showed that the PHP hadn't volatility during this period. The GDP growth was in the positive range from 7.63 in 2010 to 6.09 in 2014 . Philippines current account balance was still positive. In 2010, Philippine's current account balance was 3.59 and increased in 2014 to 4.44 (\% of GDP).

\section{f) Singapore}

The financial crisis also impacted the Singapore Dollar (SGD). This was seen during 1997-1998. The $\varnothing_{1}$ parameter was valued negative and significant. This indicated a positive feedback trading during this period. 
The $\varnothing_{1}$ huge parameter denoted that fluctuation occurred in a small range. Therefore, Singaporean Dollar (SGD) sloped downward to its lowest on January $12^{\text {th }}, 1998$ at point 1791 . Meanwhile, the SGD $\varnothing_{2}$ parameter termed as positive and significant. This exhibited that positive feedback trading was more intense during this appreciation rather than depreciation. Although the SGD was quite stable, GDP growth decreased from 8.29 in 1997 to -2.22 in 1998. The inflation based on consumer price also adjusted. It sank from 2.0 in 1997 to -0.26 in 1998. The SGD had a significant $\varnothing_{0}$ (positive) and $\varnothing_{1}$ (negative) parameter during 2007-2008. This indicated that there were a bandwagon effect and positive feedback trading behavior. This economic situation impacted Singapore's GDP growth. It went down from 9.11 in 2007 to 1.7 in 2008 along with the increasing number of inflation from 2.09 in 2007 to 6.51 in 2008. Singapore's current account balance in this period was 25.97 in 2007 and sloped down to 14.4 (\% of GDP).

Table 7. Singapore Estimation Result

\begin{tabular}{|c|c|c|c|c|c|c|c|c|c|c|c|}
\hline No Countries & Periods & Model & a & $k$ & $\phi 0$ & $\$ 1$ & $\Phi 2$ & ao & a. & $\beta 1$ & \\
\hline 6) Singapore & $02 / 01 / 1995-31 / 12 / 1996$ & GARCH $(1,1)$ & 0,0000177 & $-2,2472 E+01$ & $-0.121883^{*}$ & $-2318,9100$ & 2,11E-02 & $0,000000498 * *$ & $0,368049 *$ & $0,579737^{* \star}$ & $0,972402^{* *}$ \\
\hline & & & 0,8266 & 0,2193 & 0,0555 & 0,7321 & 0,7441 & 0,0068 & 0,0007 & 0,0000 & 0,0000 \\
\hline & $1 / 1 / 1997 \cdot 31 / 12 / 1998$ & GARCH $(1,1)$ & 0,0000901 & 0,237784 & 0,051853 & $-1317.534^{*}$ & $0.133241^{*}$ & 1,21E-07 & $0.125286^{* *}$ & $0.890436^{* *}$ & $0.968537^{* *}$ \\
\hline prob & & & 0,5011 & 0,7738 & 0,3028 & 0,0414 & 0,0169 & 0,2293 & 0,0002 & 0.0000 & 0.0000 \\
\hline & $2007-2008$ & GARCH $(1,1)$ & $-0,0000558$ & 4,489112 & $0.104117^{\star}$ & $-4484.978^{* *}$ & 0,004011 & 0.0000000269 & $0.000646^{* *}$ & $0.99742^{* *}$ & $1.765285^{* *}$ \\
\hline prob & & & 0,7256 & 0,548 & 0,0366 & 0,0006 & 0,9328 & & 0,0227 & 0.0000 & 0.0000 \\
\hline & After global crisis & GARCH $(1,1)$ & 0,000101 & $.0,515869$ & $-0,018236$ & $-1114,308$ & $-0,062631$ & $0.000000108^{*}$ & $0.075689^{* *}$ & $0.916008^{* *}$ & $1.393457^{* *}$ \\
\hline prob & $\operatorname{Dec} 2010-2014$ & & 0,4174 & 0,9681 & 0,6638 & 0,521 & 0,225 & 0,0509 & 0,0000 & 0,0000 & 0,0000 \\
\hline
\end{tabular}

${ }^{*}$ sig at $0.1 ;{ }^{* *}$ sig at 0.01

There was a sign of volatility in the SGD during 2010-2014. But there was no $\varnothing$ significant parameter that denoted volatility affected by positive feedback trading, asymmetric trading, bandwagon or contrarian effect. Singapore's GDP growth decreased from 15.24 in 2010 to 2.91 in 2014. During this period, the current account balance was fluctuated but still at 
the range between 17-23 (\% of GDP). The current account balance in Singapore was 23.66 in 2010 and in 2015 it was valued 19.08 (\% of GDP).

\section{g) Brunei Darussalam}

During 1997-1998, Brunei's currency had $\varnothing_{1}$ negative and significant parameter. It indicated a positive feedback trading behavior during this period. Therefore, the currency pushed to its lowest on August $6^{\text {th }} 1998$, at point 2.0112. On contrary, the GDP growth increased from -1.47 in 1997 to 0.55 in 1998. Meanwhile, the inflation based on consumer price decreased from 1.7 to -0.44 in 1998. The Brunei Dollar (BND) had a significant $\varnothing_{0}$ (positive) and $\varnothing_{1}$ (negative) parameter during 2007-2008. It indicated a presence of bandwagon effect and positive feedback trading behavior. Such as Singapore, the $\varnothing_{1}$ parameter was valued negative and had a large number. This showed a positive feedback trading in this period even affected it a small range of fluctuation. Brunei's GDP growth declined from 0.15 in 2007 to -1.9 in 2008. The inflation based on consumer price was increasing from 0.96 to 2.08 in 2008. Brunei's current account balance climbed up from 39.42 in 2007 to 48.2 (\% of GDP) in 2008.

Table 8. Brunei Darussalam Estimation Result

\begin{tabular}{|c|c|c|c|c|c|c|c|c|c|c|c|}
\hline No Countries & Periods & Model & a & $k$ & $\phi_{0}$ & $\phi_{1}$ & $\Phi 2$ & ad & $a_{1}$ & $\beta 1$ & \\
\hline 7 Brunei D. & 02/01/1995-31/12/1996 & NO ARCH EFFECT & & & & & & & & & \\
\hline & & & & & & & & & & & \\
\hline & 1/1/1997-31/12/1998 & GARCH $(1,1)$ & 0,00000535 & $-0,111147$ & 0,004022 & $-40.99186^{*}$ & $-0,000969$ & $0.000000583^{* *}$ & $0.020133^{* *}$ & $0.873668^{* *}$ & * $0.918024^{* *}$ \\
\hline prob & & & 0,9788 & 0,9523 & 0,8471 & 0,0277 & 0,9681 & 0,0000 & 0.0000 & 0.0000 & 0.0000 \\
\hline & 2007-2008 & GARCH $(1,1)$ & $-0,000252$ & 12,86418 & $0.099232^{*}$ & $-5255.174^{* *}$ & $-0,035262$ & 0.000000000416 & 0.000284 & $1.004222^{* *}$ & $1.356014^{* *}$ \\
\hline prob & & & 0,1222 & 0,446 & 0,0631 & 0,0063 & 0,5844 & 0,955 & 0,9228 & 0.0000 & 0.0000 \\
\hline & After global crisis & GARCH $(1,1)$ & $3,77 E-05$ & 5,011454 & $-0,03235$ & $-207,2297$ & $-0,049652$ & $0.000000105^{*}$ & $0.066026^{* *}$ & $0.925894^{* *}$ & $1.267054^{* *}$ \\
\hline prob & Dec 2010-2014 & & 0,7519 & 0,7158 & 0,4022 & 0,8814 & 0,3249 & 0,0684 & 0,0000 & 0,0000 & 0,0000 \\
\hline
\end{tabular}

*sig at $0.1 ;{ }^{* *} \operatorname{sig}$ at 0.01

During 2010-2014, after financial crisis period, there was a volatility in the BND, but It had no significant $\varnothing$ parameter. It indicated that the volatility wasn't affected by positive feedback trading, asymmetric trading, 
bandwagon nor contrarian effect. The GDP growth was fluctuated during this period but inclined from -1.7 in 2013 to 5.3 in 2014. In 2012, the current account balance was 33.52 (\% of GDP).

\section{h) Cambodia}

Cambodian exchange rate during 1997-1998 had $\varnothing 0$ negative and significant parameter. During the Asian financial crisis period, Cambodian currency had a contrarian effect. The Cambodian Riel (KHR) had a $\varnothing_{2}$ positive and significant parameter. Hence, it indicated an asymmetric trading behavior during this period. In other words, a positive feedback trading was more intense during appreciation rather than depreciation. The lowest point of the Cambodian exchange rate had been recorded at point 4015 on July $24^{\text {th }}, 1998$. The GDP growth also declined from 5.61 in 1997 to 14.8 in 1998. Based on consumer price, the inflation climbed up from 7.96 in 1997 to 14.8 in 1998 . The KHR had a $\varnothing_{1}$ (negative) and significant parameter during 2007-2008. During this period, the KHR termed as positive feedback trading behavior and had a big number in $\varnothing_{1}$ parameter. It was assessed as a positive feedback trading. Although it affected a small range of fluctuation. Cambodia's economic system impacted the GDP growth. It sloped downward from 10.21 in 2007 to 6.69 in 2008. In 2007, the inflation based on consumer price was hitting 7.6 and increased to 24.9 in 2008 . 
Table 9. Cambodia Estimation Result

\begin{tabular}{|c|c|c|c|c|c|c|c|c|c|c|c|}
\hline No Countries & Periods & Model & a & $k$ & Q0 & $\$ 1$ & $\$ 2$ & ad & a. & $\beta_{1}$ & \\
\hline \multirow[t]{3}{*}{ 8Cambodiz } & $02 / 00 / 1995-31 / 12 / 199$ & NOARCH EFEECT & & & & & & & & & \\
\hline & & & & & & & & & & & \\
\hline & 1/1/1997-31/12/1998 & GARCH|(1,1) & 9,3E-15 & $2,22 E-10$ & $0.0000000184^{*}$ & $\cdot 0,00000340$ & $00000245^{*}$ & $5,55 E-10$ & $0.019988^{+* t}$ & $0.988011^{1+t}$ & $0.092395^{* t}$ \\
\hline \multirow[t]{2}{*}{ prob } & & & 0,9882 & 0,5163 & 0,085 & 0,1641 & 0,02 & & 0.0000 & 0.0000 & 0.0000 \\
\hline & $2007-2008$ & $\operatorname{GARCH}(1,1)$ & 0,000000849 & 1,74776 & 0,004716 & $-1389.41^{2+2+}$ & 0,005051 & $0.00000255^{5 *}$ & $0.420766^{*+*}$ & $0.722677^{3+t}$ & $0.575157^{4+}$ \\
\hline \multirow[t]{2}{*}{ prob } & & & 0,9692 & 0,5025 & 0,6307 & 0.0000 & 0,5011 & 0,0073 & 0,0006 & 0.0000 & 0.0000 \\
\hline & After global crisis & $\operatorname{GARCH}(1,1)$ & $1,99 E-07$ & .0391192 & $.0201847^{7 *}$ & 204,7175 & $.0 .04100^{*}$ & $0,000000100^{1+t^{*}}$ & $0,38611^{1+*+}$ & $0,721907^{7 t}$ & $0,590749^{4+1}$ \\
\hline prob & Dec2010-2014 & & 0,9966 & 0,8898 & 0,0000 & 0,4182 & 0,0782 & 0,0000 & 0,0000 & 0,0000 & 0,000 \\
\hline
\end{tabular}

*sig at $0.1 ; *$ sig at 0.01

Cambodia's current account balance went down from -4.9 (\% of GDP) in 2007 to -7.9 (\% of GDP) in 2008. At the end of 2010 until 2014, after the financial crisis period, the KHR had a contrarian effect. It was demonstrated by a $\varnothing_{0}$ negative and significant parameter. The KHR was also valued $\varnothing_{2}$ negative and had a significant parameter. It showed an asymmetric trading behavior during that period and denoted that positive feedback trading was more intense during depreciation rather than appreciation. Cambodia's GDP growth indicated well because of the increase point from 5.9 in 2010 to 7.03 in 2014. But Cambodia's current account balance sloped downward from -3.64 (\% of GDP) in 2010 to -10.55 (\% of GDP) in 2013.

\section{i) Myanmar}

Myanmar Kyat or MMK had no ARCH effect during the Asian financial crisis (1997-1998). On April 2nd, 2012 until December 31 ${ }^{\text {st }}, 2014$, Myanmar already applied managed floating regime. But in fact, Myanmar still experienced no ARCH effect. Myanmar exchange rate was hitting its lowest point at 6.44002 on August 1st, 1997. Myanmar GDP growth increased in the very small range from 5.65 in 1997 to 5.86 in 1998. Meanwhile, the inflation based on consumer price increased from 29.69 in 1997 to 51.4 in 1998. After the crisis period, during 2010-2014, the MMK 
indicated no ARCH effect. The economic growth in Myanmar was counted as stable. It had 8.24 point in 2013 and 8.49 point in 2014. But the current account balance sloped down from -1.68 in 2012 to -1.92 in 2013 . After Myanmar exerted economic system from peg to SDR to managed floating system, the exchange rate moved from 6.41 to 818 Kyat on April 2nd, 2012.

\section{j) Laos}

Such as the Myanmar Kyat, the Laos Kip Rate (LAK) hadn't any ARCH effects during the Asian financial crisis 1997-1998. It also happened during 1995-2014. There was no ARCH effect in the LAK. Though the LAK sloped downward to its lowest with 4203.50 points on December $11^{\text {th }}, 1998$. The GDP growth also decreased from 6.87 in 1997 to 3.96 in 1998. Meanwhile, the inflation based on consumer price went higher from 27.5 in 1997 to 90.98 in 1998. There was ARCH effect in the LAK during 2007-2008.

Tabel 10. Laos Estimation Result

\begin{tabular}{|c|c|c|c|c|c|c|c|c|c|c|c|}
\hline No Countries & Periods & Model & a & $k$ & $\phi 0$ & $\$ 1$ & $\phi_{2}$ & ao & a1 & $\beta 1$ & \\
\hline 10 Laos & 02/101/1995-31/12/1996 & 6 NO ARCHEFFECT & & & & & & & & & \\
\hline & & & & & & & & & & & \\
\hline & 01//01/1955-31/12/201 & 4 NO ARCHEFFECT & & & & & & & & & \\
\hline prob & & & & & & & & & & & \\
\hline & 1/1/1997-31/12/1998 & NO ARCHEFFECT & & & & & & & & & \\
\hline prob & & & & & & & & & & & \\
\hline & 2007-2008 & GARCH $(1,1)$ & $0.000152^{* *}$ & $-194.9292 * *$ & -0.092729 & $-142721.6^{*}$ & $-0.075832^{* *}$ & $0.000000223^{*}$ & $0.22255^{1 *}$ & $0.770992^{* *}$ & $0.562965^{* *}$ \\
\hline prob & & & 0.0000 & 0.0000 & 0,1978 & 0,0531 & 0.0000 & 0,0366 & 0,0063 & 0.0000 & 0.0000 \\
\hline & After global crisis & NO ARCHEFFECT & & & & & & & & & \\
\hline prob & Dec 2010-2014 & & & & & & & & & & \\
\hline
\end{tabular}

${ }^{*}$ sig at $0.1 ;{ }^{* *}$ sig at 0.01

The research found that the LAK was in $\varnothing_{1}$ (negative) and $\varnothing_{2}$ (negative) significant parameter. It exhibited a positive feedback trading during this period. A $\varnothing_{2}$ parameter showed that an asymmetric trading behavior and a positive feedback trading was more intense during depreciation rather than appreciation. It impacted the GDP growth. The GDP growth was relatively increasing from 7.59 in 2007to 7.82 in 2008. The inflation rate (based on 
consumer price) climbed up from 4.52 in 2007 to 7.62 in 2008. During the period 2010-2014, ARCH effect didn't show in the LAK. It indicated the currency hadn't volatility during this period. The Laos GDP growth obtained 8.52 point in 2010 but slowly downward to 7.45 in 2014. The Laos current account balance also sloped down from 0.4 in 2010 to -3.36 (\% of GDP) in 2013. In the end, the LAK exchange rate fluctuated from 7500 until 8100 in this period. 


\section{2 Exchange Rate Volatility Spillover in the ASEAN Countries}

In addition to analyzing the influence of positive and negative feedback trading on ASEAN exchange rate volatility, we are also very keen to analyze the exchange rate volatility spillover across the countries. For this purpose, we developed the six-variable VAR model consisting of countries' exchange rate volatility. In its operations, we exclude three ASEAN countries, namely Brunei Darussalam, Cambodia and Myanmar because of constraints on the data's availability. However, this exclusion does not significantly reduce the validity of the estimation, since the six countries used, namely Indonesia, Malaysia, the Philippines, Singapore, Thailand, and Vietnam have greatly represented the ASEAN economy. To be noticed, the contribution of these six countries reaches 95 percent relative to the ASEAN economy (ASEAN Statistics, 2015).

Following Diebold and Yilmaz (2012) we adopt the generalized VAR framework in identifying the spillover condition of the exchange rate in the ASEAN region. This method allows us to identify the relative contributions of own variables and other variable shocks to the forecast error variance decomposition (FEVD) of each variable in the VAR model which is calculated and displayed in tabular form. The spillover table indicates the relative importance of cross variance shares or spillover in each variable. Therefore, the spillover index indicates the degree of interaction among the variables present in the model (Conefrey et al., 2013).

In line with Diebold and Yilmaz (2012), who developed the methodology proposed in Diebold and Yilmaz (2009), we utilize the generalized VAR framework to measure the spillover between variables. This approach allows us to identify the relative contribution of own variables shock and other variables shocks to the forecast error variance for each variable in the 
VAR model which are calculated and shown in tabular form. The spillover index table provides a measure of the relative importance of the cross variance shares, or spillovers, and thus indicates the degree of interaction between the variables (Conefrey \& Cronin, 2015). Another advantage of using Diebold and Yilmaz (2012) is it is more informative because this method also allows us to capture the evolution of the spillovers' patterns over time by using a rolling window estimation. The starting point for the analysis is the following $P^{\text {th }}$ order, K-variable VAR (Antonakakis et al., 2015) $y_{t}=\sum_{p=1}^{p} \theta i y_{t-i+\varepsilon_{t}}(1)$

Where $y_{t=\left(y_{1 t}, y_{2 t}, \ldots, y_{k t}\right)}$ is a vector of endogenous variables, $\Theta \mathrm{i}, \mathrm{i}=1, \ldots, \mathrm{P}$, are $\mathrm{K} \times \mathrm{K}$ parameter matrices and $\varepsilon_{\mathrm{t}} \sim(0, \Sigma)$ is a vector of disturbances that are independently distributed over time,

$t=1, \ldots, T$ is the time index.

Critical to the dynamics of the system is the moving average representation of Model (1), which is given by $y_{t}=\sum_{j=0}^{\infty} A j \varepsilon_{t-j}$, where the $\mathrm{K} \times \mathrm{K}$ coefficient matrices $A j$ are recursively defined as

$A j=\Theta_{1} A_{j-1}+\Theta_{2} A_{j-2}+. .+\Theta_{p} A_{j-p}$ where $A_{o}$ is the $\mathrm{K} \times \mathrm{K}$ identity matrix and $A_{j}=0$ for $\mathrm{j}<0$

In line with Diebold and Yilmaz (2012), we adopt the generalized VAR framework of Koop et al. (1996) and Pesaran et al. (1998), which allows us to have variance decompositions that are invariant to the variable's ordering. Based on this methodology, the H-step-ahead forecast error variance decomposition is (Antonakakis et al., 2015):

$\emptyset_{i j}(H)=\frac{\sigma_{J J}^{-1} \sum_{h=0}^{H-1}\left(e^{\prime} A_{h} \sum e_{j}\right)^{2}}{\sum_{h=0}^{H-1}\left(e^{\prime} A_{h} \sum A_{h} e_{i}\right)}$ 
Where $\Sigma$ is the (estimated) variance matrix of the error vector $\varepsilon$. $\sigma_{i i}$ the (estimated) standard deviation or the error term for the $j$ th equation and $e_{i}$ a selection vector with one as the ith element and zero otherwise. This yields a $\mathrm{K} \times \mathrm{K}$ matrix $\emptyset(H)=\left[\emptyset_{i j}(H)\right]_{i, j=1, \ldots K}$,

where each entry in this matrix shows the contribution of variable $\mathrm{j}$ to the forecast error variance of variable i. To be noticed, the main diagonal elements contain the (own) contributions of shocks of the variable $i$ to its own forecast error variance, the off-diagonal elements provide the (cross) contributions of the other variables $\mathrm{j}$ to the forecast error variance of the variable i (Antonakakis et al.,2015).

Because of the own and cross variables' variance contribution shares do not sum to one under the generalized decomposition, each entry of the variance decomposition matrix should be normalized by its row sum (Antonakakis et al., 2015)

$\widetilde{\emptyset}_{i j}(H)=\frac{\emptyset_{i j(H)}}{\sum_{j=1}^{K} \emptyset_{i j}(H)}$

With $\sum_{j=1}^{K} \widetilde{\emptyset}_{i j}(H)=1$ and $\sum_{i, j=1}^{K} \widetilde{\emptyset}_{i j}(H)=K$ by construction

This ultimately allows us to define a total(volatility) spillover index as

$$
\begin{gathered}
T S(H)=\frac{\sum_{i, j=1, i}^{K} i \neq j \widetilde{\emptyset}_{i j}(H)}{\sum_{i, j=1}^{K} \widetilde{\emptyset}_{i j}(H)} x 100 \\
T S(H)=\frac{\sum_{i, j=1,}^{K} i \neq j \widetilde{\emptyset}_{i j}(H)}{K} x 100
\end{gathered}
$$

Which indicates the average contribution of spillovers between all the observed variables to the total forecast error's variance. Another advantage of this methodology is its flexibility which allows us to gain more comprehensive insights by providing us with the calculation of directional 
spillovers, that is the directional spillovers earned by variable i from all other variables $j$,

$D S_{i \leftarrow j}(H)=\frac{\sum_{j=1, j}^{K} \neq i \widetilde{\emptyset}_{i j}(H)}{\sum_{i, j=1}^{K} \widetilde{\emptyset}_{i j}(H)} \times 100$

$D S_{i \leftarrow j}(H)=\frac{\sum_{j=1, j \neq i}^{K}, \widetilde{\emptyset}_{i j}(H)}{K} x 100$

and the directional spillovers transferred by variable i to all other variables j as

$D S_{i \rightarrow j}(H)=\frac{\sum_{j=1, j}^{K} \neq i \widetilde{\emptyset}_{j i}(H)}{\sum_{i, j=1}^{K} \widetilde{\emptyset}_{j i}(H)} \times 100$

$D S_{i \rightarrow j}(H)=\frac{\sum_{j=1, j}^{K} j \neq i \widetilde{\emptyset}_{j i}(H)}{K} \chi 100$

By calculating these directional spillovers, we can decompose the total spillovers into those coming from (or to) a particular variable. This decomposition of the total spillovers is called the net spillover. For example, we can calculate the net spillover of the variable $i$ to all other variables $j$ by subtracting Equation (6) with Equation (5). So that, in this case, we have the net spillover formula,

$N S_{i}=D S_{i \rightarrow j}(H)-D S_{i \leftarrow j}(H)$

The net spillover formula, as illustrated by Equation (7), contains information on how much market (variable) shares to the movement in other markets. It can be concluded that the spillover table shows how intense the interdependence between sectors (or variables) and because of its flexibility, it is possible to decompose the spillover effects based on their source and recipients. 
In table 11, we show spillover indices estimation for each variable based on 10- days ahead of the forecast error variance decomposition. For information, the ijth entry is an estimated contribution to the fevd of the variable $\mathrm{i}$ derived from innovation or shock to variable $\mathrm{j}$. The diagonal element $(i=j)$ represents the own-variable spillovers, while the off-diagonal element measures the cross-variable spillovers. The total spillover index (TSI) is equal to the sum of off-diagonal elements relative to the sum of total column (including the diagonal elements) that is expressed in percentage (Antonakakis et al., 2015; Diebold et al. 2012).

Table 11. Exchange Rate Volatility Spillover Index

\begin{tabular}{|c|c|c|c|c|c|c|c|}
\hline \multicolumn{8}{|c|}{ From $(j)$} \\
\hline $\operatorname{To}(i)$ & Vol_Ina & Vol_Thb & Vol_Php & Vol_Sgd & Vol_Myr & Vol_Vnd & From \\
\hline & & & & & & & Others \\
\hline Vol_Ina & 77.74 & 19.55 & 0.67 & 0.61 & 0.69 & 0.73 & 22.3 \\
\hline Vol_Thb & 19.05 & 79.15 & 0.45 & 0.19 & 0.77 & 0.39 & 20.9 \\
\hline Vol_Php & 1.53 & 2.40 & 95.40 & 0.31 & 0.34 & 0.02 & 4.6 \\
\hline Vol_Sgd & 7.41 & 17.79 & 1.34 & 72.55 & 0.91 & 0.01 & 27.4 \\
\hline Vol_Myr & 2.36 & 3.73 & 0.16 & 1.11 & 92.59 & 0.04 & 7.4 \\
\hline Vol_Vnd & 1.44 & 2.69 & 0.01 & 0.19 & 0.03 & 95.65 & 4.4 \\
\hline $\begin{array}{l}\text { Directional } \\
\text { to Others }\end{array}$ & 31.8 & 46.2 & 2.6 & 2.4 & 2.7 & 1.2 & 86.9 \\
\hline Directional & & & & & & & \\
\hline Including & 109.5 & 125.3 & 98.0 & 75.0 & 95.3 & 96.8 & $14.5 \%$ \\
\hline Own & & & & & & & (TSI) \\
\hline
\end{tabular}


Based on the information presented in table 4, it is known that the average value of exchange rate volatility spillover across countries -as indicated by the value of TSI- is 14.5 percent. It means that approximately 14.5 percent of the fevd of the variables comes from spillovers. The TSI, which receive a value of more than 10 percent, shows that exchange rate volatility spillover among the ASEAN countries to be relatively high.

Indonesia and Thailand have the largest directional spillover to others with the value of 31.8 and 46.2 percent respectively. This means that the spillover of exchange rate volatility from both countries has a relatively greater contribution to the exchange rate volatility of other countries in ASEAN. In the case for Indonesia, part of its total directional spillover to others is contributed to the value of directional spillover to Thailand. Meanwhile, for Thailand, its total value of directional to others is largely contributed by the spillover which is transmitted to Indonesia and Singapore.

Directional including own, which shows a value greater than 100 percent in Indonesia and Thailand, is indicating that both countries are responsible for the magnification of exchange rate spillovers across the countries. It means that the exchange rate volatility spillovers originating in both countries have a substantial impact on the dynamics of exchange rate volatility in other countries in ASEAN. Fundamentally, this could be happened due to the economic size of Indonesia and Thailand are bigger than the other four countries that are being analyzed (ASEAN Statistics, 2015).

Furthermore, although the average calculation of exchange rate volatility spillovers has provided good insight regarding the exchange rate volatility in the region, however, this approach may mask interesting 
findings related to the pattern of the spillovers evolution under a particular situation. Related to this concern, we are interested to analyze how total spillovers evolve over time and whether they are affected by major economic events, such as economic crisis. For this purpose, following Diebold et al. (2012); Antonakakis et al. (2015), we do a rolling window estimation. In our case, we will estimate the six-variable VAR model using 200-days rolling window in order to obtain the variance decompositions, so that we have the total spillover indices in a time-varying fashion.

The estimation results are shown in the figure below:

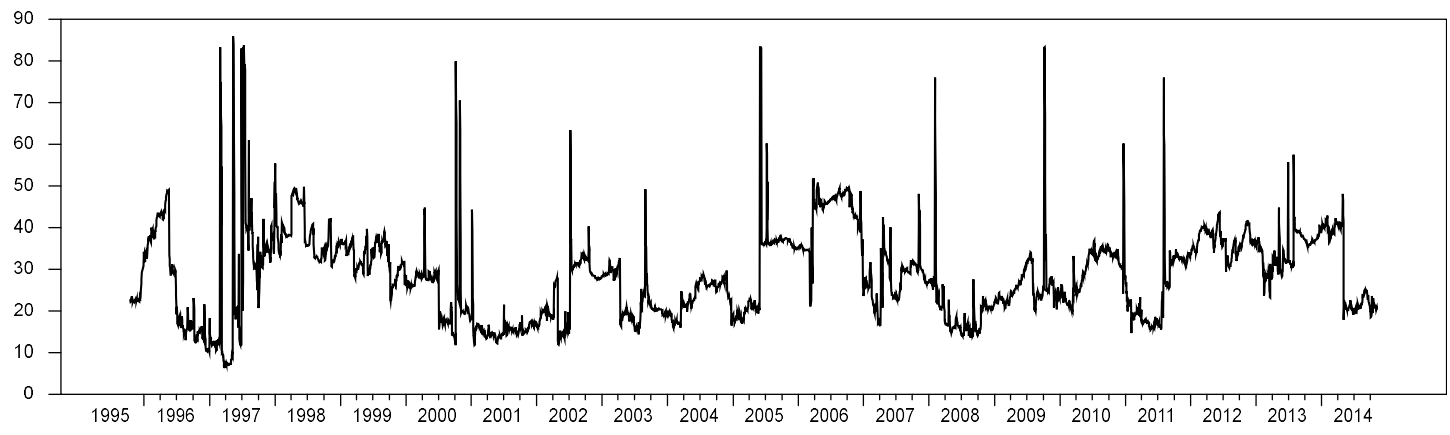

Source: Data Processed (2018)

Figure 1. Plots of the Time-Varying Exchange Rate Volatility Spillover Indices Based on 200-days Rolling Window Estimation

The value of the spillover index of exchange rate volatility in ASEAN with 200-days of rolling window is found to vary over time. Although varied, the trend of time-varying of total spillovers is relatively high. An interesting fact that is known from the estimation results of time-varying total spillovers is that there is a tendency of exchange rate volatility spillovers to increase in certain economic conditions, such as the Asian financial crisis and the US financial crisis. This indicates that there is a strong tendency of interaction among the countries' exchange rate volatility 
spillovers during the crisis period. This research finding that showed there was an increasing interconnectedness between variables during the period of crises is consistent with the findings of Claessens et al. (2011), Antonakakis et al. (2015).

\subsection{Structural breaks test}

It's called a structural break when a time series abruptly changes at a point in time. This change could involve a change in mean or a change in the other parameters of the process that produce the series. Being able to detect when the structure of the time series changes can give us insights into the problem we are studying. Structural break tests help us to determine when and whether there is a significant change in our data. We made structural breaks test of the return and the result is here: 


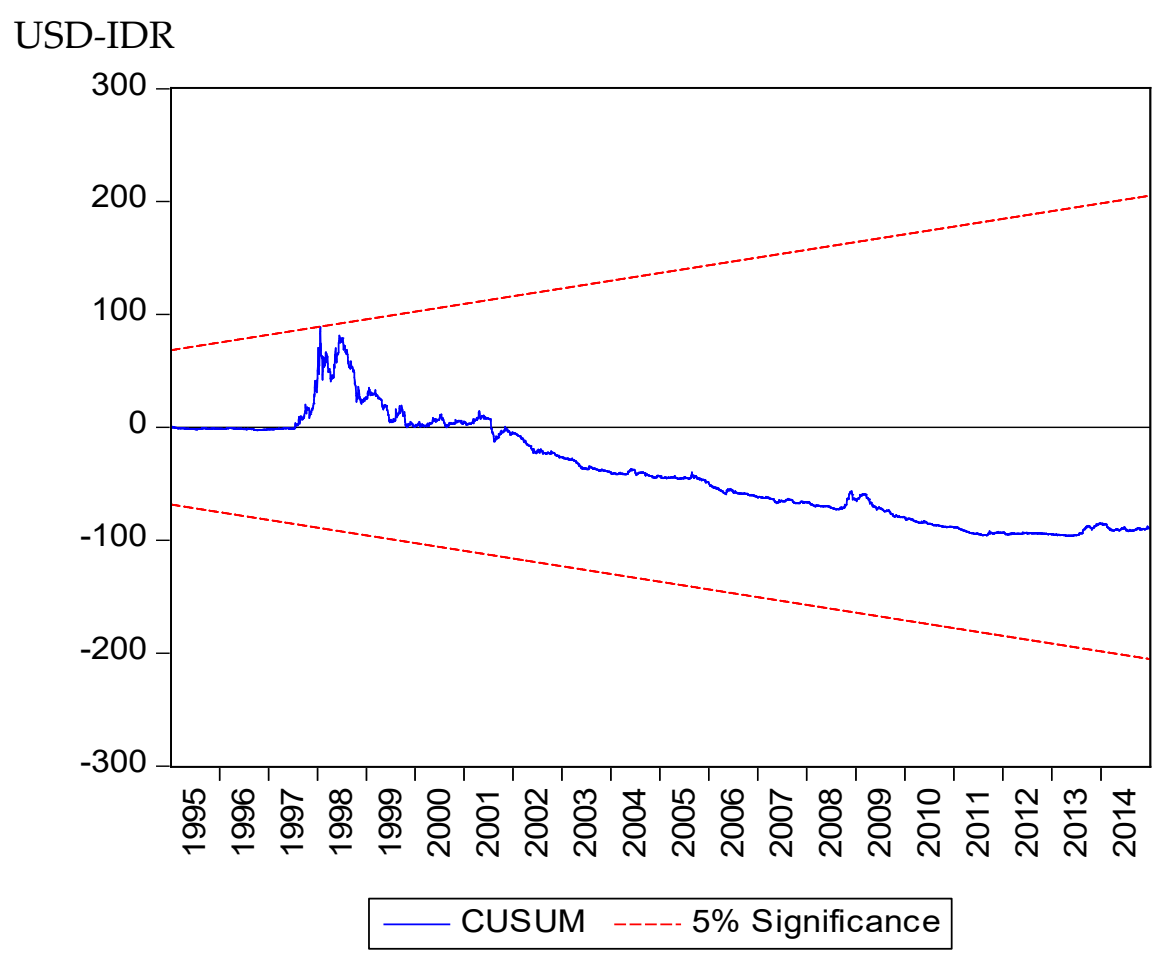

USD-BND

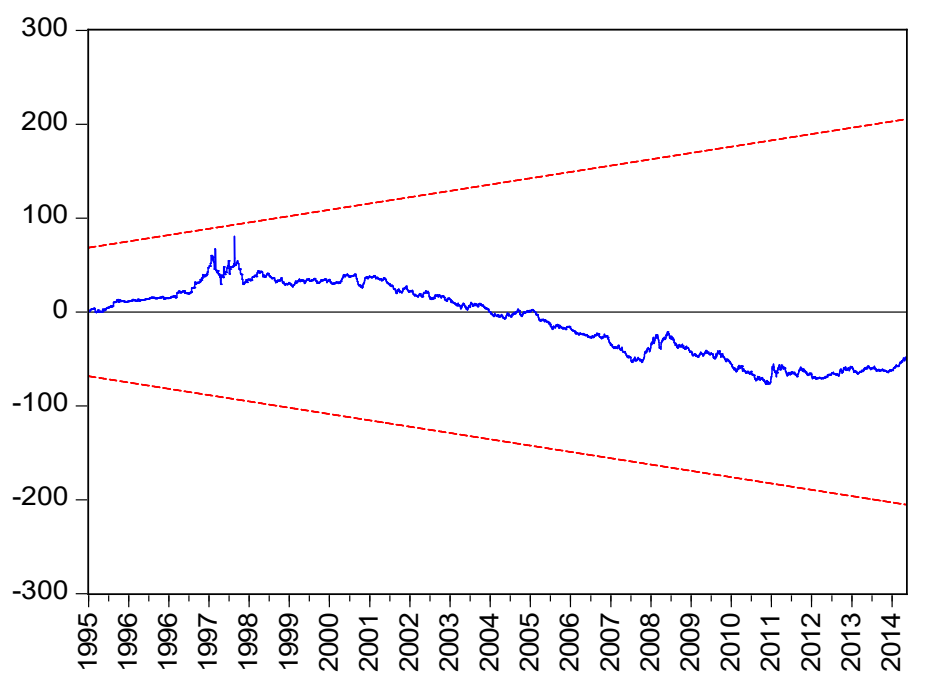

- CUSUM ---- 5\% Significance 


\section{USD KHR}

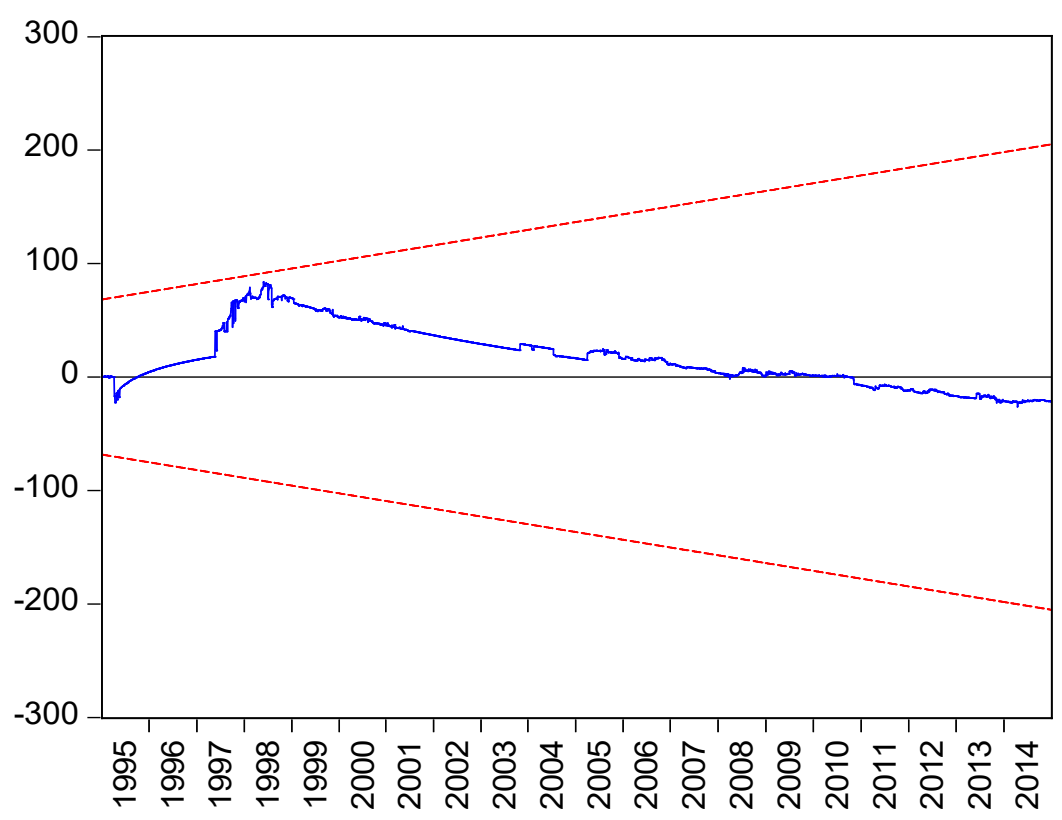

CUSUM ----- 5\% Significance

USD LAK

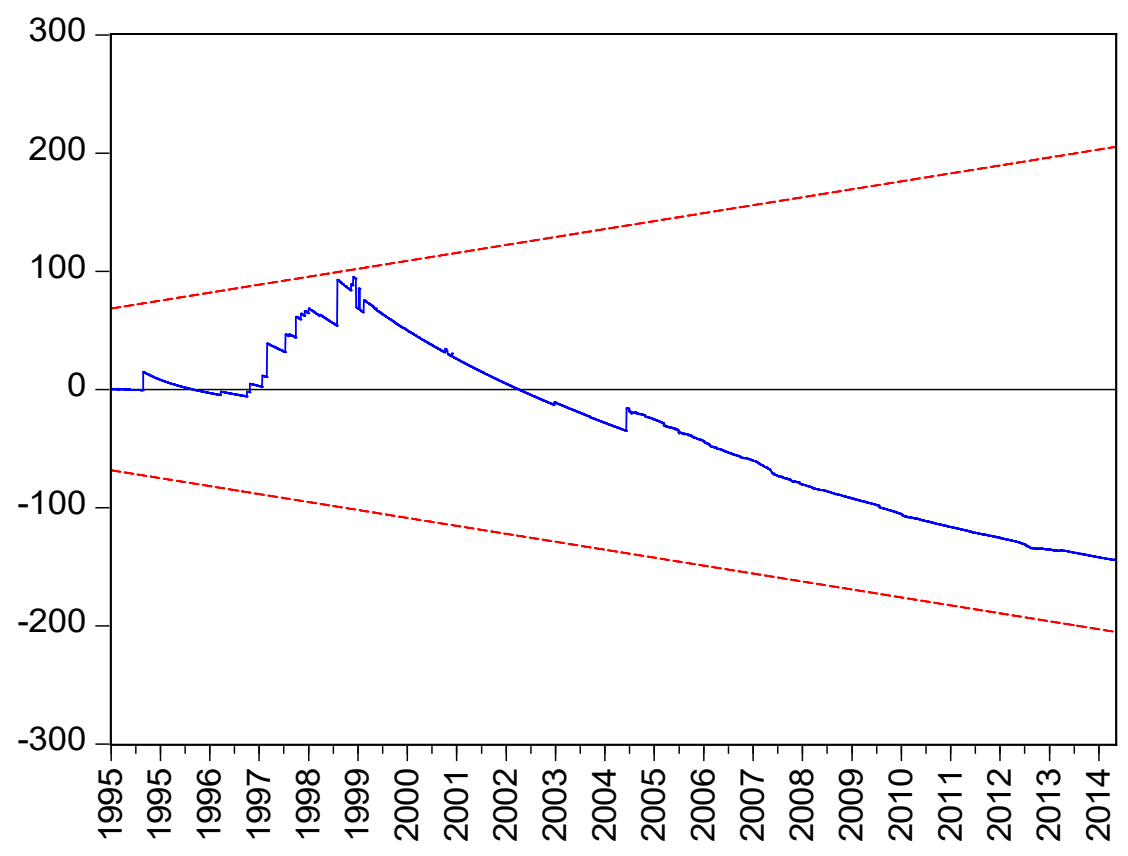

_ CUSUM ----- 5\% Significance 
USD MMK

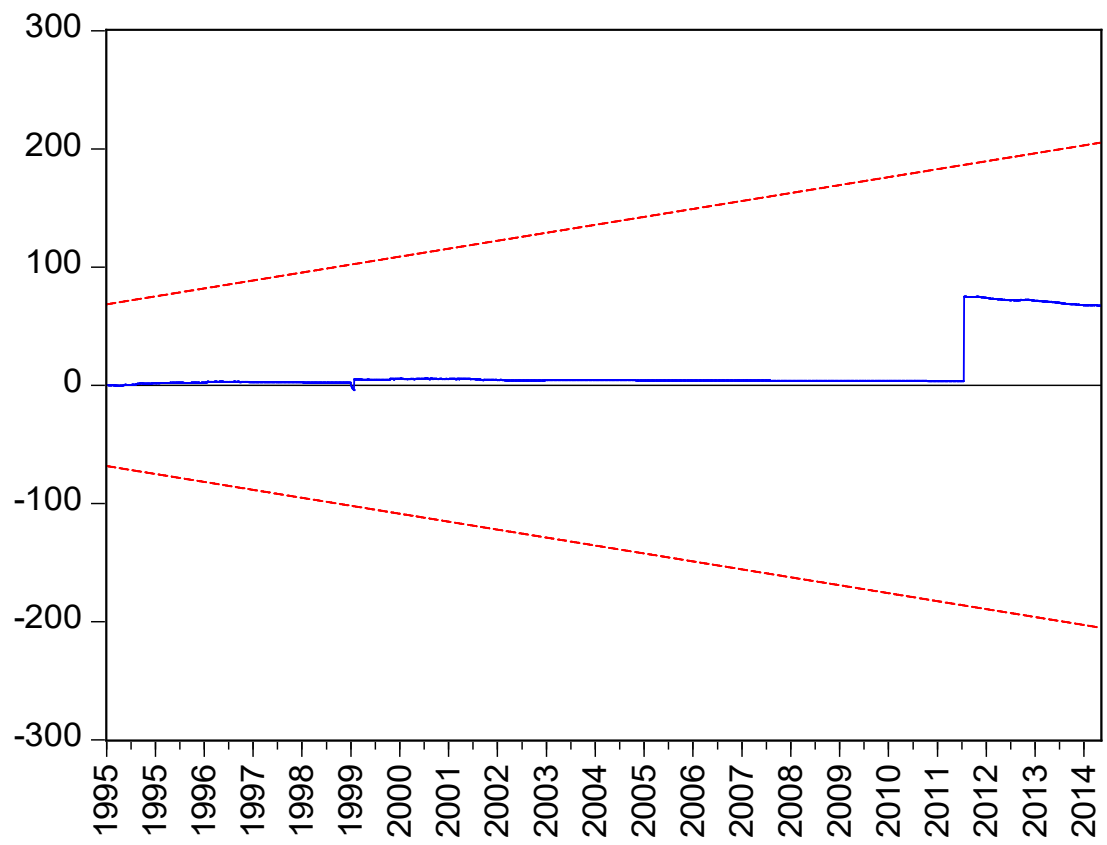

USD MYR

- CUSUM ----. 5\% Significance

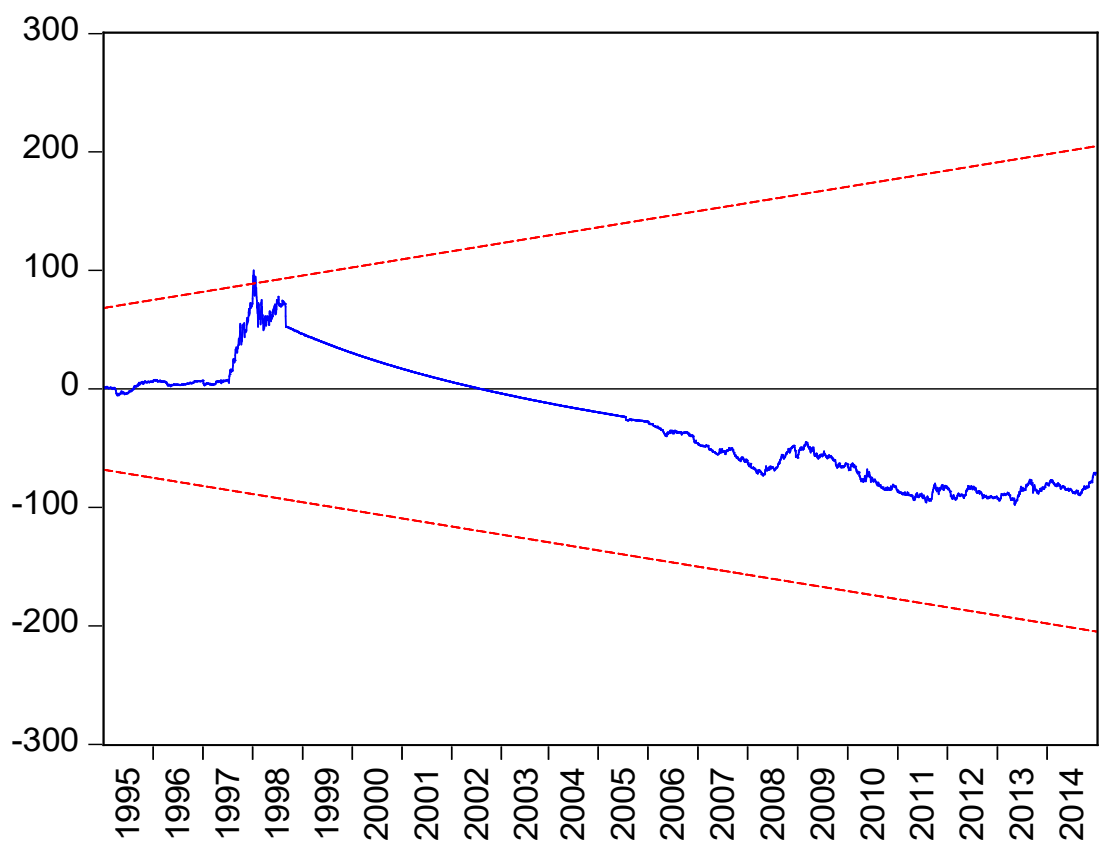

- CUSUM ----- 5\% Significance 
USD PHP

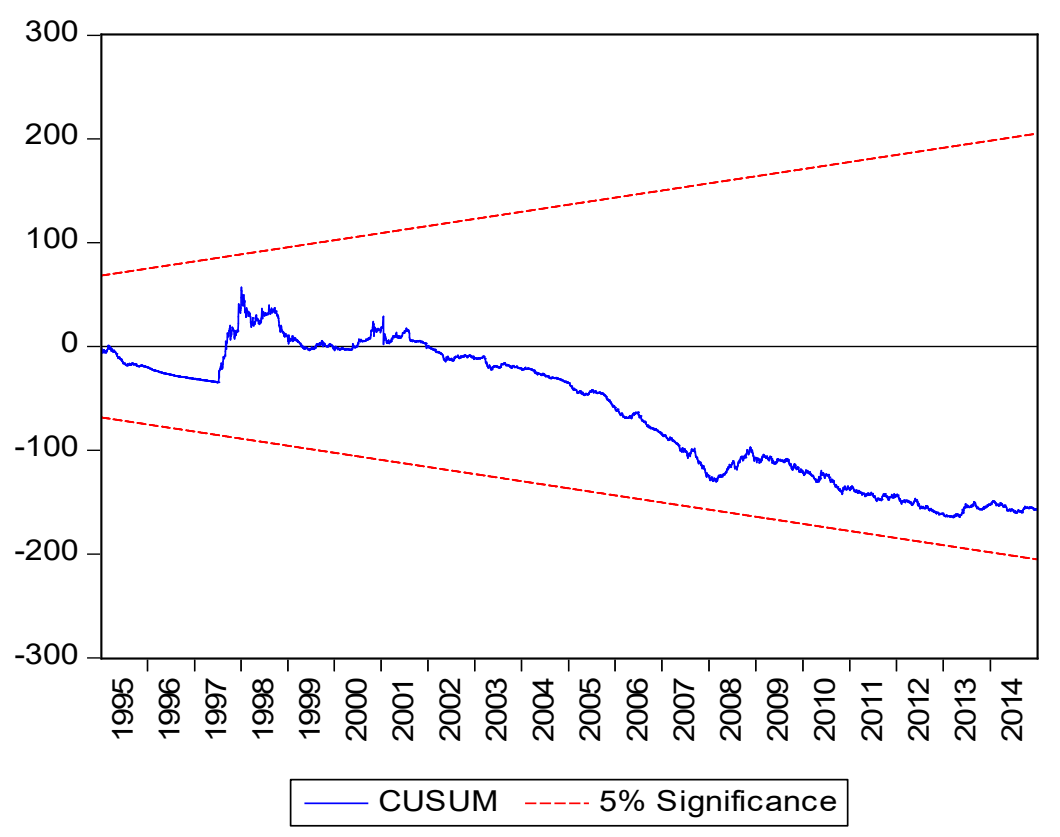

USD SGD

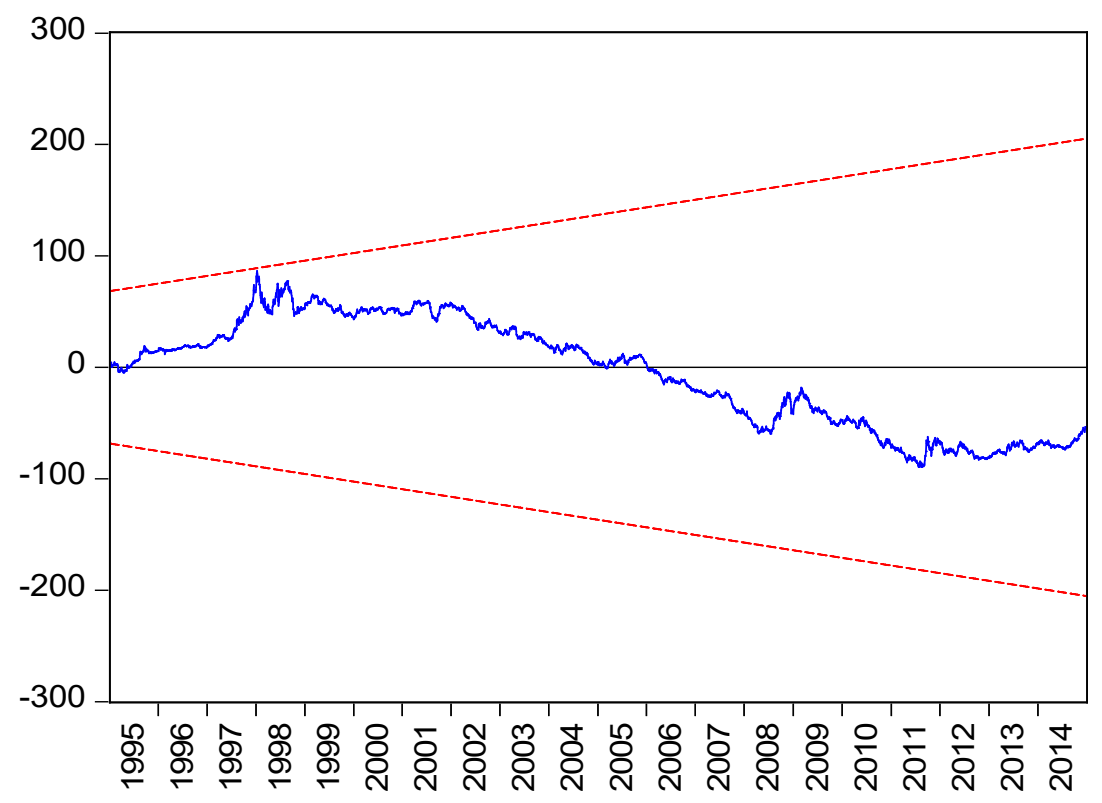

— CUSUM ---- 5\% Significance 
USD THB

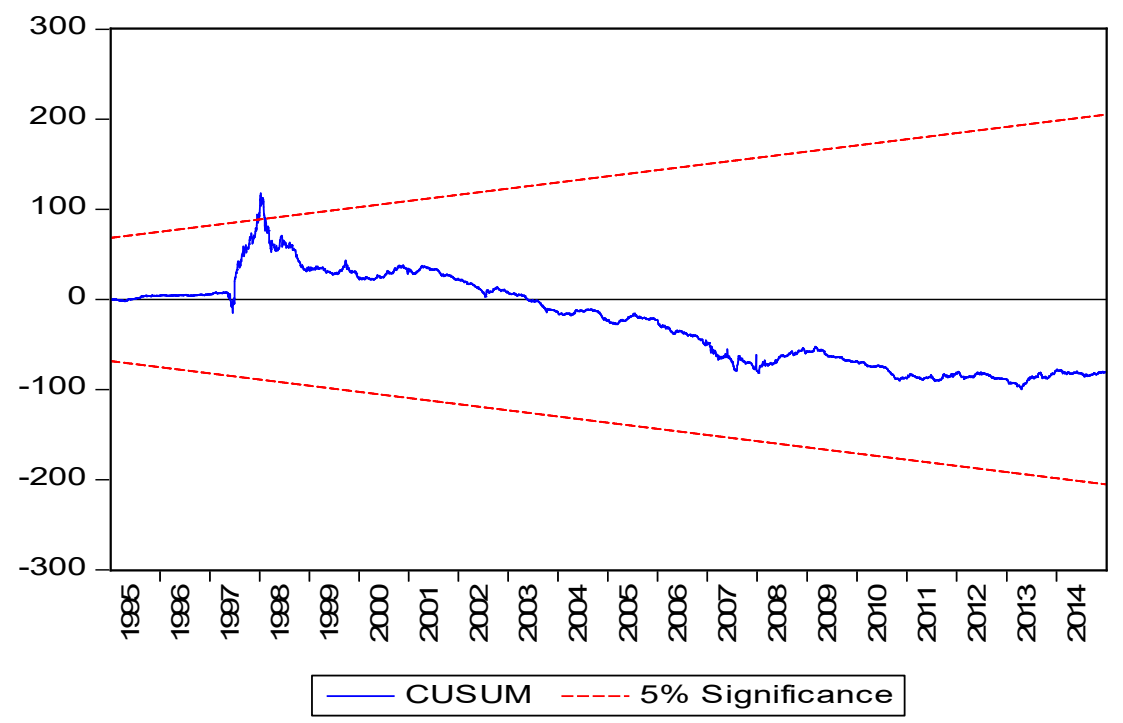

USD VND

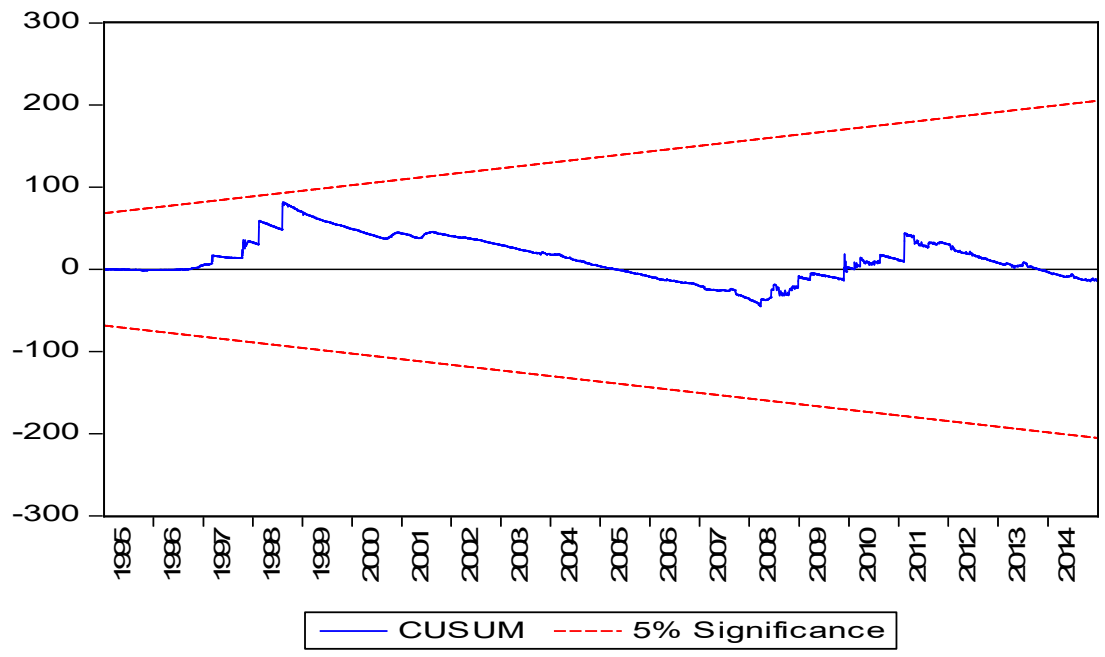

From the graphics above, we see that the IDR, MYR, SGD, and THB have significance CUSUM test at 1998 which means in 1998 crisis have significantly changed the data. 


\section{CONCLUSION}

The objective of this study is to analyze the autocorrelation in exchange rate parameters and volatility in key ASEAN markets to yield the deeper understanding of inducted exchange rates induced by the actions of positive feedback traders. In addition to this concern, we also try to identify the exchange rate volatility spillover in the ASEAN. Related to the above, we found several important findings. First, the positive feedback trading is the main cause of the high volatility and weakening the exchange rate value. However, during 1995-2014, most of ASEAN currencies hadn't positive feedback trading except Singapore. But the condition is different when we analyze the data in more detail by investigating the sub-periods where during the Asian financial crisis 1997/98, most of all ASEAN currencies demonstrated a significant positive feedback trading. The crisis also affected the GDP growth and the inflation to almost all ASEAN countries. Second, the US financial crisis during 2007-2008 exhibited no significant impact through all ASEAN currencies. This impact can be seen from no ARCH sign such as in Indonesia, in Philippine, and in Myanmar. Meanwhile, Malaysia, Singapore, Brunei, Cambodia, and Laos had a volatility in their exchange rate. Hence, their exchange rate indicated positive feedback trading. Fluctuation also occurred in a small range. Thailand and Vietnam experienced a volatility without a sign of positive feedback trading. No ARCH effect in several periods affected by no volatility in currency movement of several countries. We don't exclude these countries because we want to show the characteristics of the exchange rates of each ASEAN country despite the different results of each country. For example, Myanmar and Laos applied a managed floating system. Third, in the context of exchange rate volatility spillover, we found that 
Indonesia and Thailand play a dominant role as the transmitter of exchange rate volatility in the ASEAN region. Fourth, in the context of time-varying fashion, the total spillovers tend to increase in a certain economic condition, such as economic crises. This research finding that showed there was an increasing interconnectedness between variables during the period of crises is consistent with the findings of Claessens et al. (2011), Antonakakis et al. (2015). 


\section{REFERENCES}

Antonakakis, N., M. Breiteniechner, and Johann, S. Johann, 2015. “Business Cycle and Financial Cycle Spillover in the G7 Countries". The Quarterly Review of Economics and Finance, 58, 154-162.

Berndt, Hall, Hall, and Hausman. (1974). Estimation and Inference in Nonlinear Structural Model. Annals of Economic and Social Measurement, 3/4,1974.

Bodie, Z., Kane, A., \& Marcus, AJ. (2011). Investments and portofolio Management. Global Edition. New York: The McGraw-Hill Companies, Inc.

Bohl, M., \& Reitz, S. (2002). The Influence of Positive Feedback Trading on Return Autocorrelation: Evidence for the German Stock Market, Working Paper Series of Postgraduate Research Programme.

Brock, W., Hommes, C., (1998). Heterogeneous beliefs and routes to chaos in a simple asset pricing model. Journal of Economic Dynamics and Control 22, 1235-1274.

Claessens, S., M. A. Kose., E. T. Marco, 2011. “Financial Cycles: What? How? When?". IMF Working Paper /11/76.

Conefrey, T., D. Cronin, 2013. "Spillover in Euro Area Sovereign Bond Markets". Central Bank of Ireland: Research Technical Paper, Vol. 5.

De Grauwe, P., Grimaldi, M.(2006). Exchange rate puzzles: A tale of switching attractors. European Economic Review50, 1-33.

De Long, J.B., A. Shleifer, L.H. Summers, and R.J. Waldmann. (1990). Noise Trader Risk in Financial Markets. Journal of Political Economy 98 (4):703-38. 
Diebold, F. X., K. Yilmaz, 2009. “Measurement Financial Assets Return and Volatility Spillover, with Application to Global Equity Market". Economic Journal, 119, $158-171$.

Diebold, F. X., K. Yilmaz, 2012. “Better to Give than to Receive: Predictive Measurement of Volatility Spillover". International Journal of Forecasting, 28, $57-66$.

Federal Reserve. (November, 3, 2010). Press Release. http://www.federalreserve.gov/newsevents/press/monetary/201011 03a.htm

Frankel, J., Froot, K.(1987). Understanding the US dollar in the eighties: The expectations of fundamentalists and chartists. Economic Record.

Hien, MAMT. (2007). Solutions for exchange rate policy of transition economy of Vietnam. Dissertation zur Erlangung des Grades Doktor der Wirtschaftswissenschaft (Doctor rerumpoliticarum, Dr. rer. pol.) der Juristischen und WirtschaftswissenschaftlichenFakultät der Martin Luther-Universität Halle-Wittenberg.

Hommes, Cars H. (2005). Heterogeneous Agent Models in Economics and Finance, Tinbergen Institute Discussion Paper, No. 05-056/1

Hoontrakul, Pongsak. (2001). Contagion in S. E. Asia Measuring Stock Market Co-Movement. Available at SSRN: http://ssrn.com/abstract=293319 or http://dx.doi.org/10.2139/ssrn.293319

International Monetary Fund.(2006). De Facto Classification of Exchange Rate Regimes and Monetary Policy Framework. Accepted from http://www.imf.org/external/np/mfd/er/2006/eng/0706.htm 
International Monetary Fund.(2011). Lao People's Democratic Republic-Staff Report; Staff Supplement; Public Information Notice on the Executive Board Discussion; and Statement by the Executive Director for Lao P.D.R. Accepted from http://www.imf.org/external/pubs/ft/scr/2011/cr11257.pdf

International Monetary Fund.(2014). Annual Report on Exchange Arrangements and Exchange Restrictions 2014. www.imf.org/external/pubs/nft/2014/areaers/ar2014.pdf

Keynes, J.M. (1936). The General Theory of Unemployment, Interest and Money. Harcourt, Brace and World, New York.

Krugman, Paul R., and Obstfeld, Maurice. (2009). International Economics: Theory and Policy $8^{\text {th }}$ ed. Boston: Pearson Addison-Wesley

Laopodis, NT. (2005). Feedback trading and autocorrelation interactions in the foreign exchange market: Further evidence. Economic Modelling $22,811-827$

Le Baron, B. (1992). Some relations between volatility and serial correlations in stock market returns. Journal of Business 65, 199-219.

Messe, Richard \& Rogoff, Kenneth.(1983). The Out-of-Sample Failure of Empirical Exchange Rate Models: Sampling Error or Misspecification?,NBER Chapters, in: Exchange Rates and International Macroeconomics, pages 67-112 National Bureau of Economic Research, Inc

Nelson, D.B. (1991). Conditional Heteroskedasticity in Asset Returns: A New Approach. Econometrica, vol. 59, no. 2, pp. 347-370. 
Sentana, E., and S. Wadhwani.(1992). Feedback Traders and Stock Return Autocorrelations: Evidence from a Century of Daily Data. Economic Journal102: 415-425.

Thaler, R. H. (2005). Advances in Behavioral Finance (Vol. 2). Princeton, New Jersey: Princeton University Press.

Yoon, Il-Hyun.(2006). Financial Crisis Theories Explaining the 1997 Thai Financial Crisis. Thammasat Economic Journal Vol.24, No. 1, March 2006. 